\title{
Mesoscale numerical analysis of the historical November 1982 heavy precipitation event over Andorra (Eastern Pyrenees)
}

\author{
L. Trapero ${ }^{1,2}$, J. Bech ${ }^{2}$, F. Duffourg ${ }^{3}$, P. Esteban ${ }^{1,4}$, and J. Lorente ${ }^{2}$ \\ ${ }^{1}$ Snow and Mountain Research Centre of Andorra - Andorran Research Institute, Sant Julià de Lòria, Andorra \\ ${ }^{2}$ Department of Astronomy and Meteorology, University of Barcelona, Barcelona, Spain \\ ${ }^{3}$ Centre National de Recherches Météorologiques - Groupe d'étude de l'Atmosphère Météorologique, Météo-France \\ - Centre National de la Recherche Scientifique, Toulouse, France \\ ${ }^{4}$ Group of Climatology, University of Barcelona, Barcelona, Spain
}

Correspondence to: L. Trapero (Itrapero.cenma@iea.ad)

Received: 5 April 2013 - Published in Nat. Hazards Earth Syst. Sci. Discuss.: 5 June 2013

Revised: 3 October 2013 - Accepted: 15 October 2013 - Published: 22 November 2013

\begin{abstract}
From 6 to 8 November 1982 one of the most catastrophic flash-flood events was recorded in the Eastern Pyrenees affecting Andorra and also France and Spain with rainfall accumulations exceeding $400 \mathrm{~mm}$ in $24 \mathrm{~h}$, 44 fatalities and widespread damage. This paper aims to exhaustively document this heavy precipitation event and examines mesoscale simulations performed by the French Meso-NH non-hydrostatic atmospheric model. Large-scale simulations show the slow-evolving synoptic environment favourable for the development of a deep Atlantic cyclone which induced a strong southerly flow over the Eastern Pyrenees. From the evolution of the synoptic pattern four distinct phases have been identified during the event. The mesoscale analysis presents the second and the third phase as the most intense in terms of rainfall accumulations and highlights the interaction of the moist and conditionally unstable flows with the mountains. The presence of a SW low level jet $\left(30 \mathrm{~m} \mathrm{~s}^{-1}\right)$ around $1500 \mathrm{~m}$ also had a crucial role on focusing the precipitation over the exposed south slopes of the Eastern Pyrenees. Backward trajectories based on Eulerian on-line passive tracers indicate that the orographic uplift was the main forcing mechanism which triggered and maintained the precipitating systems more than $30 \mathrm{~h}$ over the Pyrenees. The moisture of the feeding flow mainly came from the Atlantic Ocean $\left(7-9 \mathrm{~g} \mathrm{~kg}^{-1}\right)$ and the role of the Mediterranean as a local moisture source was very limited (2-3 $\mathrm{g} \mathrm{kg}^{-1}$ ) due to the high initial water vapour content of the parcels and the rapid passage over the basin along the Spanish Mediterranean coast (less than $12 \mathrm{~h}$ ).
\end{abstract}

\section{Introduction}

As other mountainous Mediterranean regions, Andorra (Eastern Pyrenees) is regularly affected by intense precipitation events and subsequent flash floods. The most catastrophic case for at least the last $30 \mathrm{yr}$ in terms of rainfall accumulations and human losses in Andorra (Fig. 1) took place from 6 to 8 November 1982. This episode, associated with a very strong windstorm, also affected the neighbouring areas of SE France and NE Spain (Catalonia) producing historical precipitation amounts in the Pyrenees such as the $610 \mathrm{~mm}$ recorded in $48 \mathrm{~h}$ in Py (France). Not surprisingly, excessive rainfall caused widespread damage and casualties, destruction of buildings and infrastructure with substantial economic losses. There were 13 fatal victims in Andorra (based on the Andorran police database), 15 more in France, mainly caused by uprooted trees, and 14 in Catalonia. Particularly in Andorra, the huge flood impacts on the landscape, roads and infrastructures caused important economic losses estimated at EUR 24 million (Fig. 2). This flood event is compiled among one of the major flood disasters in Europe and is included in the 1950-2005 inventory reported by Barredo (2007) and subsequent studies like Gaume et al. (2009), where preliminary analysis results conclude that the most extreme flash floods are greater in magnitude in the Mediterranean countries than in the inner continental countries. 


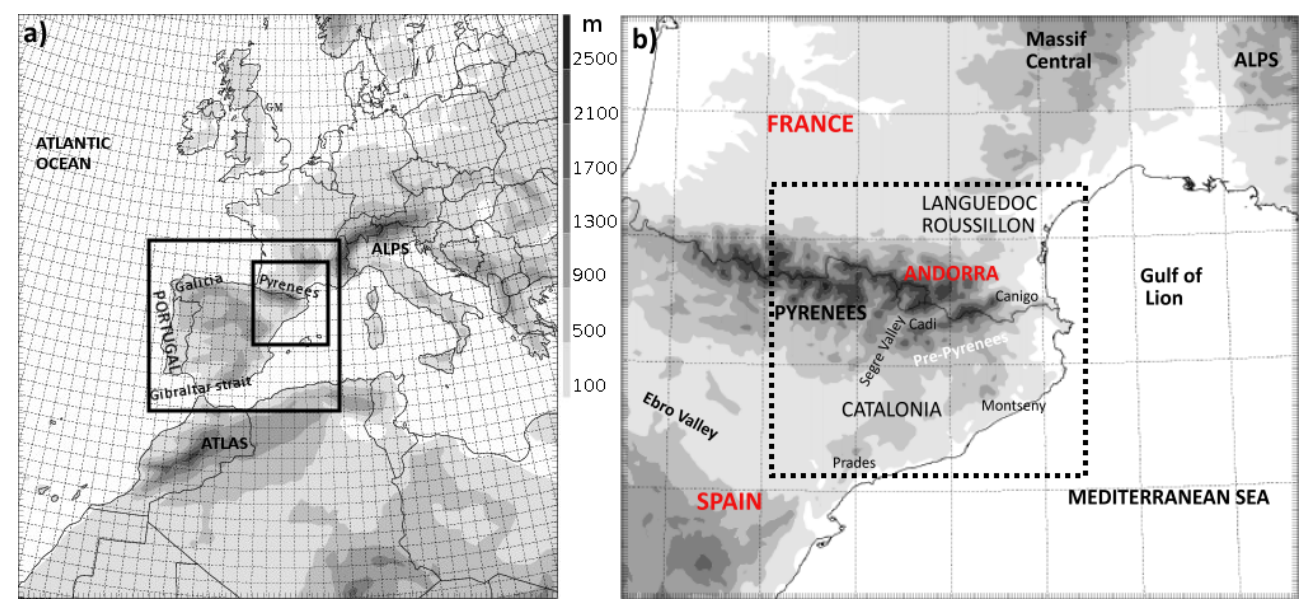

Fig. 1. (a) Area covered and topography of the coarser domain ( $40 \mathrm{~km}$ of horizontal resolution) used in the synoptic analysis. The two other nested domains $(10$ and $2.5 \mathrm{~km}$ ) used in this study are delineated by black boxes. (b) Area covered and topography defined for the inner domain $(2.5 \mathrm{~km})$ centred in Andorra (Pyrenees). The dashed box indicates the area where observations and quantitative precipitation forecast are analyzed. Different locations mentioned in the text are also shown. The orography is displayed in grey shaded colours (m).

Several studies carried out in the eighties analysed the meteorological synoptic framework which favoured the episode and examined the wind and rainfall observations from a climatological point of view, highlighting the extreme character of the event and the enhanced precipitation along the Pyrenees and Massif Central ranges (Cailleau and Santurette, 1983; Albentosa, 1983; Llasat, 1991; Marti-Bono and Puigdefabregas, 1983; Corominas and Alonso, 1990). Contrary to other catastrophic events which occurred in the Pyrennes, such as the Biescas disaster (87 people killed in a campsite) where a flash flood was caused by a short but very intense convective rainfall $(160 \mathrm{~mm}$ in $1 \mathrm{~h})$ over a small area (Riosalido et al., 1997; Gutierrez et al., 1998); the 1982 event was characterized by long-lasting stationary precipitating systems $(>30 \mathrm{~h})$ over an extended area which lead to high rainfall surface totals ( $>150 \mathrm{~mm}$ in $24 \mathrm{~h}$ over Andorra) and widespread flash floods as in the Segre river basin. As described in earlier studies the event was characterized by a synoptic environment prone to generate a heavy precipitation event over the western Mediterranean area. However, to get a better insight on the mechanisms that triggered and maintain heavy precipitation resulting in the high accumulations observed, the interaction between synoptic scale and local circulations over the complex orography of the region must be examined in detail similar to other studies carried out over other mountain regions worldwide (see Houze, 2012 for a review).

Andorra, located on the eastern half of the Pyrenees range, is $468 \mathrm{~km}^{2}$ and is the country with the highest average elevation $(2044 \mathrm{~m})$ in Europe, with a range of altitudes between $837 \mathrm{~m}$ and $2942 \mathrm{~m}$ (Comapedrosa peak). Consequently, steep mountain slopes are ubiquitous in the country, and represent a key factor in the potential occurrence of natural hazards such as landslides, rock falls, snow avalanches and flash floods (Gallego, 2003). Furthermore, in 1982 after a period of strong urban expansion during the seventies (economic boom), the vulnerability of the infrastructures, buildings and people greatly increased due to the weak territory planning efforts. As a consequence, after the event, the importance of natural hazards management in this Pyrenean country was highlighted.

From a climatic point of view, Andorra has a subMediterranean climate, characteristic of the NE part of the Iberian Peninsula. However, some features such as continental influences, the orography and the south-facing location in the Pyrenees introduce changes in the typical seasonal precipitation regimes and expected amounts as it is shown in the climatological atlas of Andorra (Batalla et al., 2011). In this way, the southerly flows usually lead to heavy precipitation events over the Pyrenees (Sotillo et al., 2003) and Andorra (Fig. 8c from Esteban et al., 2009), as in other exposed mountainous regions in southern France (Nuissier et al., 2011). Nevertheless, the low and favourably oriented orography of the French side of the Pyrenees also enables the easy entrance of Atlantic air masses, especially affecting elevated areas of the northern half of Andorra. Localized intense rainfall events triggered by diurnal forcing mainly in the summer also occur, such as the 1 August 2008 thunderstorm (Trapero et al., 2011), but in general orographic factors have been found to be instrumental in previous cases studied (Trapero et al., 2013). In summary, the Andorran area can be considered an interesting crossroad of climates (Atlantic and Mediterranean) and meteorological phenomena.

Many of the factors previously described are relevant for understanding the 1982 heavy precipitation event (HPE). This paper aims to document exhaustively and to analyze the major flash flood event recorded in Andorra. Even though 


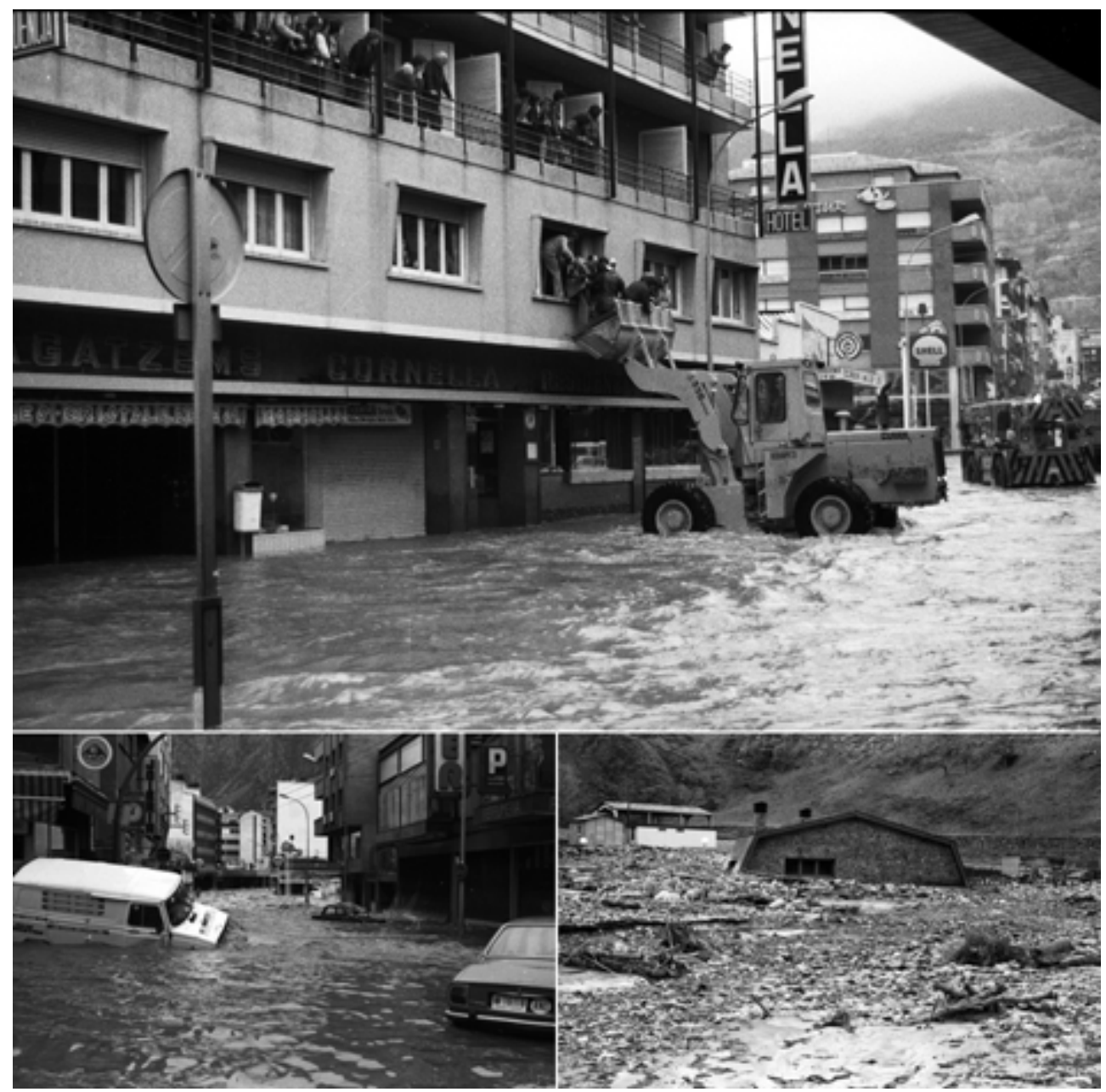

Fig. 2. Pictures of the catastrophic effects of the heavy precipitation event over Andorra in November 1982. Top picture shows the evacuation of tourists from a hotel in Andorra la Vella downtown. Bottom right image shows the important material deposition ( $2 \mathrm{~m}$ high) occurred in Aixovall (Source: Arxiu Nacional d'Andorra/Fons FPB).

earlier studies already described the synoptic-scale context of this HPE, the large-scale situation is detailed in Sect. 2 since the synoptic environment greatly governs the evolution of the atmospheric conditions. Satellite data, rainfall accumulations as well as results of a geomorphological survey are described in the following subsection. The main goal of the study is the use for the first time of a convective-scale model to obtain realistic simulations of the $1982 \mathrm{HPE}$ and to go further into the factors which lead to large rainfall accumulations over Andorra and Eastern Pyrenees. Section 3 describes the mesoscale model configuration and assesses the results of the simulations. Section 4 gives a detailed analysis of the mesoscale simulations as well as the effect of the Mediterranean Sea as a local source for moisture supply to the precipitating systems. Summary and concluding remarks are given in the final section.

\section{The case study}

\subsection{Precipitation and satellite observations}

During the morning of 6 November 1982, light precipitation started over Andorra and did not stop until two days later. As no weather radar data is available for this event, we focus our analysis of precipitation observations on daily records in Andorra, south-eastern France and Catalonia which allow characterizing local maxima and their approximate spatial distribution over the Pyrenees (Fig. 3). During the first $24 \mathrm{~h}$ of the episode, from 06:00 UTC on 6 November to 06:00 UTC on 7 November 1982 (Fig. 3a), the accumulated precipitation showed a maximum over the easternmost extreme of the Pyrenees and the Roussillon French region. Surface rainfall amounts exceeded $100 \mathrm{~mm}$ in $24 \mathrm{~h}$, and one of the stations of the Météo-France daily raingauge network recorded $260 \mathrm{~mm}$ (Py weather station). Over Andorra, the $24 \mathrm{~h}$ accumulations registered in the 


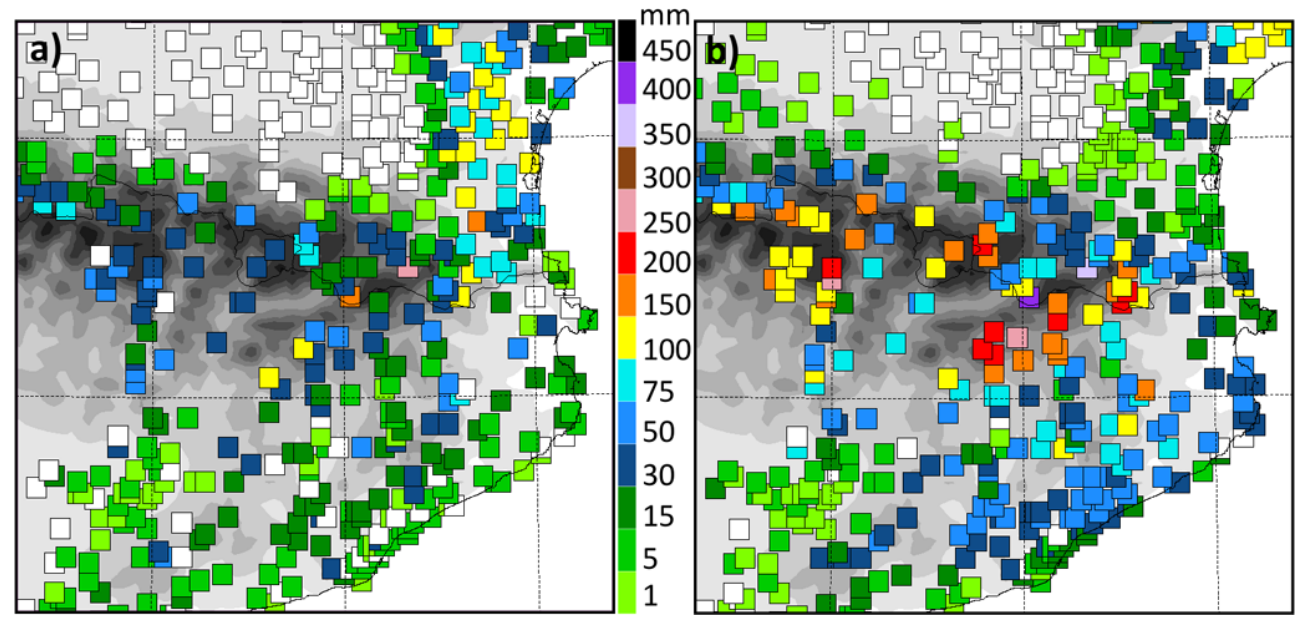

Fig. 3. The $24 \mathrm{~h}$ accumulated precipitation ( $\mathrm{mm}$ ) from Météo-France and AEMET raingauge network. Accumulations correspond to daily manual observations. (a) From 06:00 UTC on 6 November to 06:00 UTC on 7 November 1982. (b) From 06:00 UTC, 7 November to 06:00 UTC, 8 November 1982. The area represented is shown in Fig. 1b (dashed box).

valley were about $40 \mathrm{~mm}$. Additional reports (Commission Météorologique Départementale, 1982) documented that thunderstorms and convective precipitation occurred over the Languedoc-Roussillon area. In METEOSAT-2 satellite image from the visible channel on 6 November at 12:00 UTC (Fig. 4), a cold front can be recognized as a cloud band over the Atlantic Ocean. The cumulus observed to the northwest of this cloud band indicates the presence of cold air. Over the $\mathrm{NE}$ of the Iberian Peninsula orographic clouds are identified on the Pyrenees (Andorra) and the first reliefs close to the Catalan coast.

The maximum $24 \mathrm{~h}$ surface rainfall amounts of the event took place between 06:00 UTC on 7 November 1982 and 06:00 UTC on 8 November 1982 (Fig. 3b). The heaviest precipitation was located over mountainous areas over the southern slopes of the Pyrenees, especially the Pre-Pyrenees (e.g. Pobla de Lillet $266 \mathrm{~mm}$, Cabdella $252 \mathrm{~mm}$ ) and Eastern Pyrenees in France. As in the previous day, maxima were observed in French stations of Vallcebollère $(408 \mathrm{~mm})$, Py $(350 \mathrm{~mm})$ and Porté-Puymorens $(196 \mathrm{~mm})$. Daily amounts in Andorra were Ransol $(151 \mathrm{~mm})$, Escaldes $(140 \mathrm{~mm})$ and Ordino $(91.6 \mathrm{~mm})$. The $151 \mathrm{~mm}$ measured in Ransol is still the $24 \mathrm{~h}$ rainfall record in Andorra since the beginning of observations in 1948. First reliefs onshore from the Catalan coast like Montseny massif (1700ma.s.l.) also affected during the episode $(95 \mathrm{~mm})$, whereas in lower south Catalan mountain ranges (Montsant, Prades Mountains: $1200 \mathrm{~m}$ a.s.1.) precipitation did not exceed $50 \mathrm{~mm}$. The visible satellite image from 7 November at 12:00 UTC (Fig. 4) shows the typical spiral cloud structure over the Atlantic associated with the mature stage of extratropical cyclones and the wide north-south cold-frontal band located over Spain approaching the western border of Andorra. The cloud-free dry area associated with the cold air can also be recognized in the satellite image. Progressively the cold front advanced to the east, impinging a widespread area of cloudiness over Catalonia and Andorra. It must be highlighted that the cloud free slot just north of Andorra is a result of cloud evaporation in the lee side of the Pyrenees (Foehn effect).

Considering the total accumulations of the episode (from 06:00 UTC on 6 November 1982 to 06:00 UTC on 8 November 1982), extreme surface rainfall was recorded: $196 \mathrm{~mm}$ (Ransol), $566 \mathrm{~mm}$ (Vallcebollère) and $610 \mathrm{~mm}$ (Py). This last record appears among the seventh heaviest events reported over France and is greater than the mean annual precipitation collected in Paris or Barcelona. This episode also affected neighbouring Mediterranean mountain areas as the Massif Central in south France where several weather stations exceeded $400 \mathrm{~mm}$, such as Roqueredonde in Herault $(509 \mathrm{~mm})$ or Valleraugue in Gard $(476 \mathrm{~mm})$ (Météo-France, 2012).

Due to the widespread damage caused by the heavy rainfall and subsequent landslides, a geomorphologic survey was carried out by the Institut d'Estudis Andorrans (IEA) from Perpignan (France) in collaboration with the University of Paris in December 1982 (Barthélemy, 1982). The purpose of the field campaign was to map effects of precipitation in terrain movements and classify qualitatively the Andorran territory according to the estimated precipitation. The zoning resulting from the terrain analysis is reproduced in Fig. 5. Four categories were considered: (1) Normal rain - no substantial terrain movements; (2) Moderate rain strong current marks, overflows, some traces of gullies, but almost no marked resumption of erosion and accumulation; (3) Heavy precipitation - important but not catastrophic marks; (4) Extreme precipitation - catastrophic marks. The zoning over Andorra assigned category 2 to the Ransol 


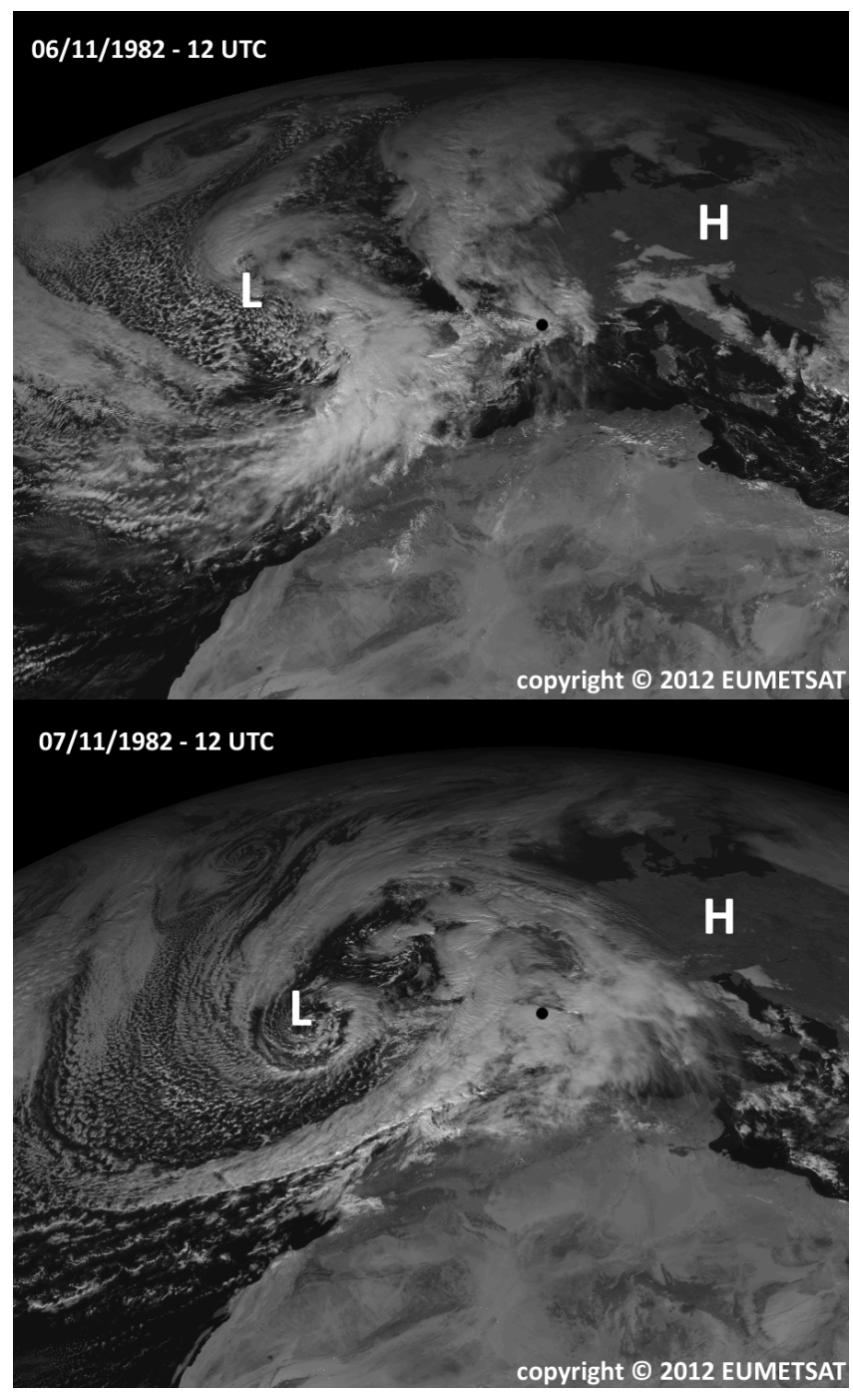

Fig. 4. Temporal evolution of the cloud cover over Europe observed in the visible channel from Meteosat-2 imagery. Top panel corresponds to 6 November 1982 at 12:00 UTC and the bottom panel to 7 November 1982 at 12:00 UTC. The black dot shows Andorra location, and the $\mathrm{L}$ and $\mathrm{H}$ identify centres of surface low and high pressure systems, respectively.

and Escaldes surface rainfall measurements located close to the river valley. Whereas over the west border of Andorra as well as in Engolasters located in the central part of the country (areas without any raingauge measurement), the observed terrain movements estimated that these zones were affected by extreme precipitation (category 4). This estimation is consistent with rainfall measurements observed in other stations located in elevated areas in the Pyrenees. The rainfall intensities inferred from the field campaign give us very valuable information in order to complement the limited density of observations available over Andorra and to validate the mesoscale numerical simulation of this episode.

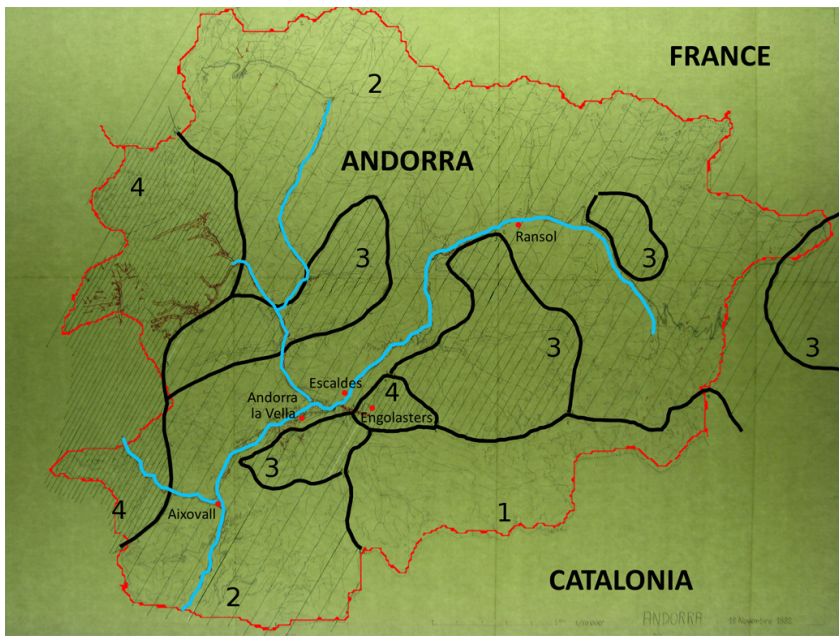

Fig. 5. Map reproduction of Andorra zoning of rainfall intensity estimation resulting from the terrain analysis made in December 1982. Four categories are considered: (1) Normal rain: no significant terrain movement; (2) Moderate rain: strong current marks, overflows, some traces of gullies, but almost no mark resumption of erosion and accumulation; (3) Heavy precipitation: important but not catastrophic marks; (4) Extreme precipitation: catastrophic marks. Different locations mentioned in the text are shown. Adapted from Barthéleny (1982).

\subsection{Synoptic overview}

An overview of the synoptic conditions from 6 to 8 November 1982 which favoured the development of the episode is described in this section. The evolution between 6 November 1982 at 12:00 UTC and 7 November 1982 at 12:00 UTC is presented in Fig. 6. The ERA-INTERIM reanalysis with approximately $80 \mathrm{~km}$ of horizontal resolution (Dee et al., 2011) has been used as initial and lateral boundary conditions by the MESO-NH model and scaled down over a domain which covers Western Europe, northern Africa and the eastern part of North Atlantic Ocean at $40 \mathrm{~km}$ horizontal resolution (Fig. 1a).

Figure 6, besides depicting mean sea level pressure and the surface wind evolution, also shows the equivalent potential temperature field $\left(\Theta_{\mathrm{e}}\right)$ and the wind at $850 \mathrm{hPa}$. At the beginning of the event, the mean sea level pressure and $10 \mathrm{~m}$ wind maps (Fig. 6a) show the presence of a strong surface cyclone $(965 \mathrm{hPa})$ centred in front of the Galician coast and an associated cold front approaching Portugal (Fig. 6e). Simultaneously, high pressure centres installed over Central and Eastern Europe are reinforced due to a Scandinavian cold air advection (see top right corner of Fig. 6e). This blocking synoptic configuration slowed down the eastward advance of the extratropical cyclone generating a strong pressure gradient over the Eastern Pyrenees. This synoptic pattern induced south-easterly winds over the NE part of the Iberian Peninsula (Fig. 6a). On 6 November at 

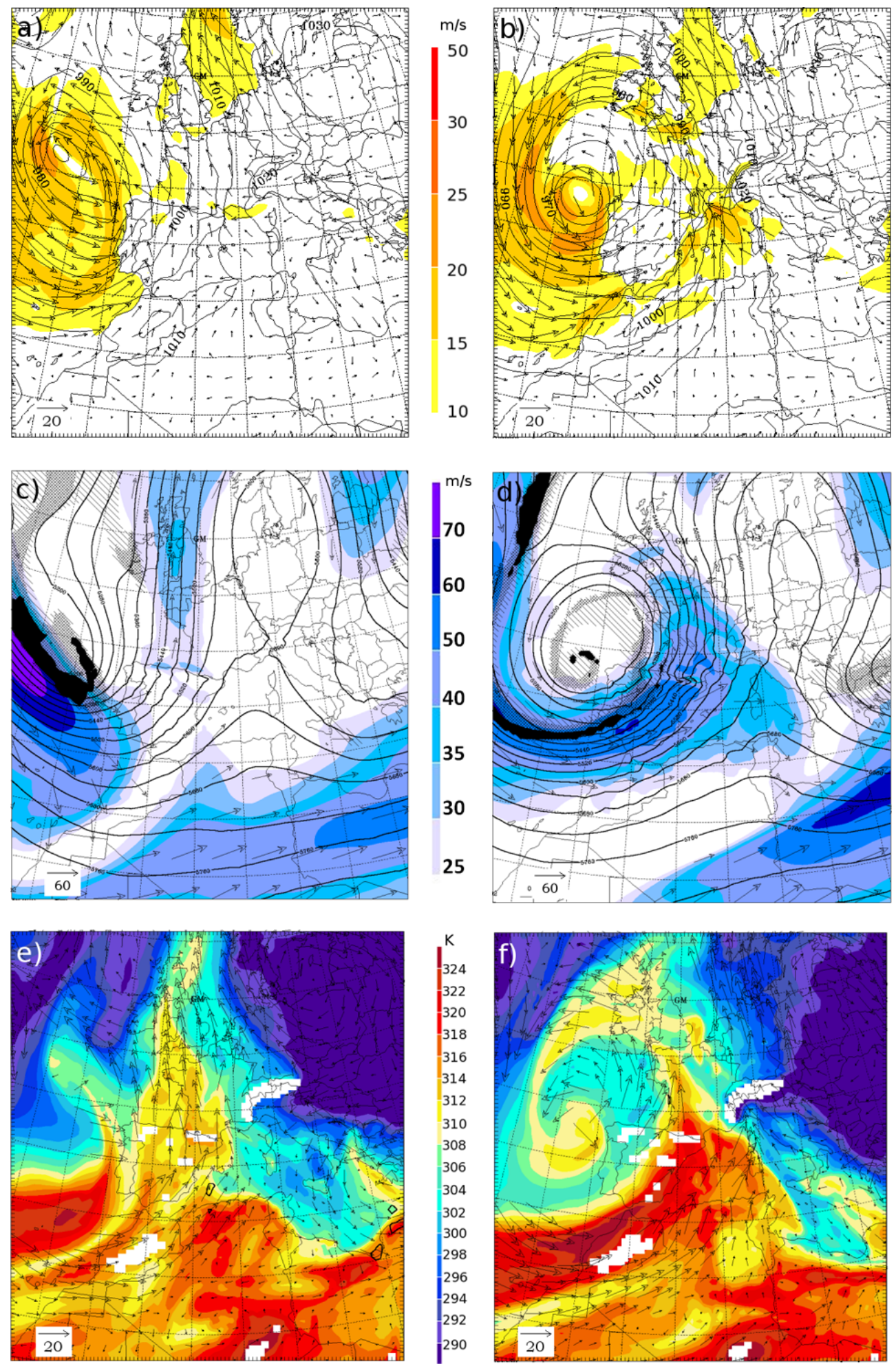

Fig. 6. Temporal evolution of the synoptic conditions: from 12:00 UTC on 6 November 1982 (first column) to 12:00 UTC on 7 November 1982 (second column). First row (a, b) shows mean sea level pressure (contour, hPa) and $10 \mathrm{~m}$ a.g.l. wind (shaded colours and arrows, $\mathrm{m} \mathrm{s}^{-1}$ ). Second row (c, d) shows $500 \mathrm{hPa}$ geopotential height (black contour, $\mathrm{m}$ ), $200 \mathrm{hPa}$ wind speed (blue shaded colours and arrows, $\mathrm{m} \mathrm{s}^{-1}$ ) and 1.5 PVU surface height (black shaded corresponds to altitudes less than $4.5 \mathrm{~km}$ ). Bottom row (e, f) shows $850 \mathrm{hPa}$ equivalent potential temperature (shaded colours, $\mathrm{K}$ ), $850 \mathrm{hPa}$ wind (arrows, $\mathrm{m} \mathrm{s}^{-1}$ ) and CAPE (black isocontour of $500 \mathrm{~J} \mathrm{~kg}^{-1}$ ). 
12:00 UTC (Fig. 6e), the equivalent potential temperature also shows a relatively warm and moist air mass over the NE part of the Iberian Peninsula, as well as the presence of two other air masses with higher $\Theta_{\mathrm{e}}$ values: the first one over the North African coast and the second one over the Atlantic Ocean (Madeira Island) ahead of the cold front. At mid-levels $(500 \mathrm{hPa})$ an elongated and pronounced trough extending from Greenland to the coast of Portugal is present (Fig. 6c). The $500 \mathrm{hPa}$ geopotential pattern above Central Europe was characterized by the presence of a persistent ridge with omega configuration (Fig. 6c and d). Simultaneously, at $200 \mathrm{hPa}$ the left exit of a jet streak was located over the Atlantic Ocean and a south-westerly diffluent flow over the Pyrenees. Moreover, on the 6 November an anomaly of the dynamical tropopause height (DTH) was present in the 1.5 PVU surface (potential vorticity unit). The anomaly appears clearly in Fig. 6c as a dark shaded band (DTH $<4.5 \mathrm{~km}$ ) extending along a northwest-southeast axis over the Atlantic associated with the trough. This upper-level anomaly is a classical synoptic scale ingredient which enhances upper-level divergence and intensifies the cyclonic winds at low atmospheric levels east of the anomaly (Hoskins et al., 1985). The gradual strengthening of the surface cyclonic winds during the afternoon of 6 November 1982 amplified the low-level temperature advection (strong temperature gradient between the polar air mass and the warm sector ahead of the front) which in turn amplified the upper-level anomaly favouring the cut-off characteristics of the upper-level circulation (Fig. 6d) (Semple, 2003). The blocking of the synoptic circulation at high levels as well as the slow-evolving anticyclonic conditions installed over Central Europe contributed during the next hours to the generation of a fast and wide south-westerly flow over the entire profile of the Iberian Peninsula. The location of the cold low at upper levels the 7 November at 12:00 UTC was in phase with the surface depression generating a deep and mature extratropical cyclone centred in the NW of the Galician coast (Fig. 6b and d). It is during this stage that winds reached their highest intensity with values greater than $15 \mathrm{~m} \mathrm{~s}^{-1}$ over Andorra, Catalonia and the southern coast of France (Gulf of Lion), where a surface convergence zone was formed (Fig. 6b). The jet stream strengthened to around $50 \mathrm{~m} \mathrm{~s}^{-1}$ (Fig. 6d) over the Pyrenees. The $\Theta_{\mathrm{e}}$ field (Fig. 6f) shows the temperature structure of a developed cyclone with a region of warm air wrapping cyclonically around the low pressure centre associated with the warm conveyor belt (Harrold, 1973) affecting the eastern half of the Iberian Peninsula. Behind this warm and moist synoptic scale flow a band of low $\Theta_{\mathrm{e}}$ shows the surface cold front approaching the Pyrenees. It is on the 7 November afternoon that the pressure centre slightly increased, the cyclone started to decay and moved north-eastward allowing the cold frontal surface to cross over the Pyrenees.
The low and upper-level slow-evolving synoptic conditions played a crucial role in the evolution of this episode, under these circumstances over Andorra (Pyrenees) the strong cyclonic flow persisted more than $36 \mathrm{~h}$ advecting directly to the Pyrenees several airflows with different thermodynamic features. Based on this synoptic analysis, the episode can be divided in four stages. The first phase started on 6 November 1982 when synoptic conditions built up the initial favouring environment (from 06:00 UTC on 6 November 1982 to 00:00 UTC on 7 November 1982), during the second phase when the Atlantic cyclonic flow was well established over the Iberian Peninsula the first warm front affected the Eastern Pyrenees (second stage: 00:00-08:00 UTC on 7 November 1982). Later on during the third phase, due to the synoptic blocking the warm and moist conveyor belt ahead of the cold front impinged on the Pyrenees for almost 10h (08:00-18:00 UTC on 7 November 1982). Finally, the cold front crossed over the Pyrenees and moved towards the Mediterranean Sea (fourth stage: at 18:00 UTC on 7 November 1982).

\section{Numerical simulation and QPF validation}

\subsection{Model settings}

The numerical simulations performed with the French non-hydrostatic research model MESO-NH (Lafore et al., 1998) aim to reproduce the precipitation systems and describe the ingredients which caused the heavy precipitation event over Andorra on 6, 7, and 8 November 1982. Three 2-way nested domains have been used with a horizontal resolutions of $40,10,2.5 \mathrm{~km}$ and 40 vertical levels. The area corresponding to the coarsest domain (D1) and their nested domains (D2, D3) are shown in Fig. 1. D1 aims to describe the synoptic environment over Western Europe, part of northern Africa and North-eastern Atlantic, D2 is centred over the Iberian Peninsula and D3 with a dimension of $600 \mathrm{~km} \times 600 \mathrm{~km}$ and $2.5 \mathrm{~km}$ horizontal resolution covers the NE Iberian Peninsula, South France, and is centred over Andorra including the entire Pyrenees massif. The initial and boundary conditions for the $48 \mathrm{~h}$ simulation of this historical episode have been provided by the ERA-Interim reanalysis from the ECMWF (Dee et al., 2011) with about $80 \mathrm{~km}$ of horizontal resolution, 60 vertical levels and $6 \mathrm{~h}$ temporal resolution. Table 1 summarizes some model configuration features. A battery of preliminary tests have been performed in order to define the domains, their horizontal resolution and the initial time of the mesoscale model in order to better capture the evolution of the atmospheric conditions.

The physical and dynamical configurations of the Meso-NH model have been selected in order to best describe the microphysical and convective processes characteristic of heavy precipitation events that take place in summer or autumn in southern France, with the remarkable influence 


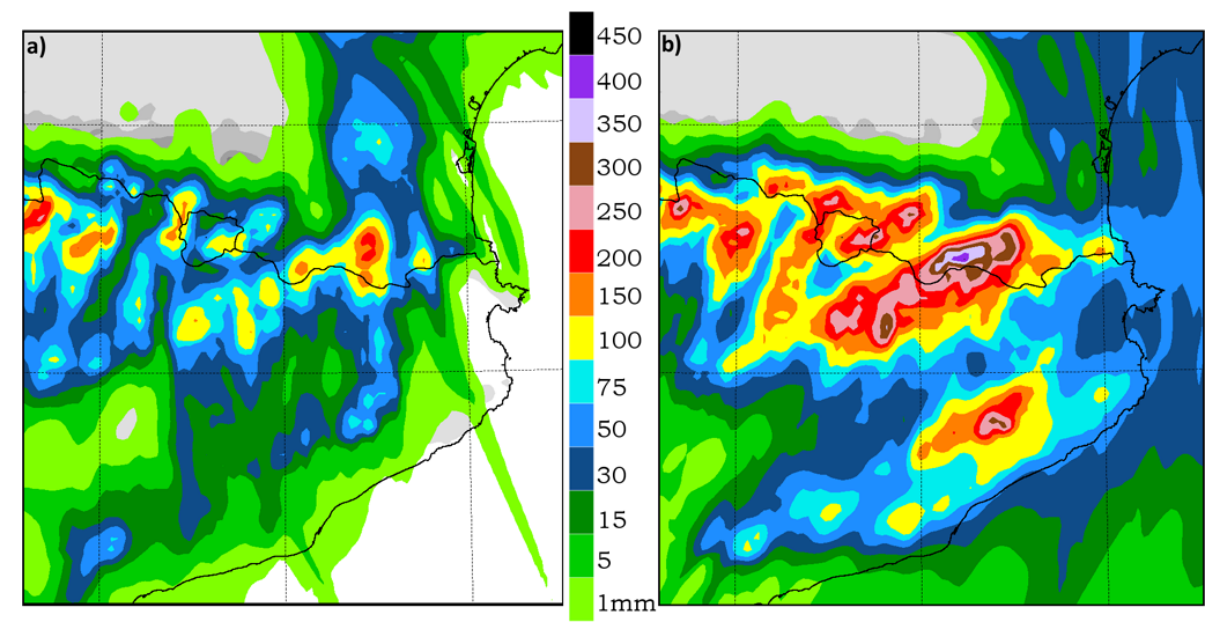

Fig. 7. Simulated $24 \mathrm{~h}$ accumulated precipitation (colour scale from 1 to $450 \mathrm{~mm}$ ). Accumulations correspond to daily time periods: (a) from 06:00 UTC on 6 November to 06:00 UTC on 7 November 1982; (b) from 06:00 UTC on 7 November to 06:00 UTC on 8 November 1982. The area represented is shown in Fig. $1 b$ (dashed box).

Table 1. Model features used for each domain configuration.

\begin{tabular}{llll}
\hline Domain & Resolution & Dimensions $(x, y, z)$ & Time step \\
\hline 1 & $40 \mathrm{~km}$ & $100 \times 108 \times 40$ & $64 \mathrm{~s}$ \\
2 & $10 \mathrm{~km}$ & $480 \times 240 \times 40$ & $16 \mathrm{~s}$ \\
3 & $2.5 \mathrm{~km}$ & $240 \times 240 \times 40$ & $4 \mathrm{~s}$ \\
\hline
\end{tabular}

of the Mediterranean Sea and of local circulations induced by complex topography. This Meso-NH model configuration was also used by Nuissier et al. (2008), Duffourg and Ducrocq (2011), Bresson et al. (2012), Fresnay et al. (2012) or Vié et al. (2012) among others. The model microphysics is based on a 1-moment mixed microphysical scheme which combines a Kessler scheme for warm processes and a three-class ice parameterization (Caniaux et al., 1994; Pinty and Jabouille, 1998) which governs the prognostic equations of the six water species defined (water vapour, cloud water, rain water, ice, snow aggregates and graupel). The representation of hydrometeors in five classes allows describing precisely the water cycle and related cloud processes. The one-dimensional turbulence parameterization is based on a 1.5-order approximation of the TKE equation (Cuxart et al., 2000). The sub-grid-scale effect of deep convection is parameterized for horizontal resolutions of 40 and $10 \mathrm{~km}$ by the Kain-Fritsch-Bechtold scheme (Bechtold et al., 2001), whereas for the $2.5 \mathrm{~km}$ inner domain no scheme for deep convection is activated as it is explicitly resolved - see for example Seity et al. (2011). Moreover, shallow convection is also parameterized and based on a particular EDMF (Eddy Diffusivity Mass Flux) scheme described in Pergaud et al. (2009).

\subsection{Quantitative precipitation forecast (QPF) validation}

Daily accumulated precipitation from 06:00 UTC on 6 November 1982 to 06:00 UTC on 8 November 1982 obtained from the MESO-NH simulations is shown in Fig. 7. These two $24 \mathrm{~h}$ periods are comparable with the only available rainfall observations presented in Sect. 2.1. In this section, before starting the mesoscale analysis of the event it should be verified that the simulations achieved to reproduce the large precipitation amounts represented in Fig. 3 and the spatial distribution matches with the observed HPE.

The rainfall pattern identified in both QPF at $2.5 \mathrm{~km}$ resolution shows the orography as one of the mechanisms which controlled the uplifts and allowed the generation of convective cells. The simulated heaviest precipitation accordingly to the observations is located over the mountains mainly in the most exposed sides on the south slope of the Pyrenees. This spatial distribution shows the uplift efficiency of the mountain range configuration to the southerly flows due to its west-east main axis and the south-north valleys orientation. Furthermore, the simulations also confirm the strong effect of the Foehn wind on the lee side of the Pyrenees, just north of Andorra, where the rainfall was very weak or non-existent due to the downslope adiabatic warming. Note that in some French locations the monthly maxima temperature records were break, for instance in Toulouse the new record was $22.5^{\circ} \mathrm{C}$, while the previous record was $22^{\circ} \mathrm{C}$ dated from November 1955 (Commission Météorologique Départementale, 1982).

The 6 November over the Roussillon region and Py location, the model underestimates the rainfall accumulation despite a well simulated north-south precipitation band. On the other hand the several maxima simulated in the Pre-Pyrenees $(>100 \mathrm{~mm})$ are very realistic, but the ones 
in the western edge of the domain are overestimated. Light widespread precipitation simulated over Catalonia $(<30 \mathrm{~mm})$ is of good quality regarding of the observed precipitation pattern. During the second 24 hour period (Fig. 7b) according to the observations the highest intensities of the event were simulated over mountainous areas. The maximum $350 \mathrm{~mm}$ in the eastern edge of the Pyrenees (Canigo massif) matches with the observed HPE. The high rainfall gradient present between the mountain peaks and the river valleys consistent with the observations is noteworthy. Moreover, a secondary maximum is well simulated in the Montseny massif despite its extension is overestimated.

Particularly over Andorra the highest intensities are simulated over the elevated terrain of the exposed eastern sides in the west and south-east border. Despite not having observations over this area, this spatial rainfall distribution obtained over Andorra - especially the maximum identified in the west border - is consistent with the rainfall accumulations estimated by the proxy data obtained from the analyses of the terrain movements (Fig. 5, category 4: Extreme precipitation). These results can be complemented by the hourly evolution of the simulated precipitation over the pixel corresponding to the location of the two Andorran meteorological weather stations (Fig. 8). The black line represents the total accumulated rainfall simulated by the model, and dark points the $24 \mathrm{~h}$ accumulative observed precipitation. Both simulations overestimate the observations taken in the narrow valley of Andorra. In such a narrow valley it is difficult to solve the altitude gradients between the peaks and the valleys; nevertheless, the $2.5 \mathrm{~km}$ model simulation reproduces the topography fairly well. In that case, the corresponding model elevation of these weather stations is $400 \mathrm{~m}$ higher than its real altitude and probably the precipitation simulated by the model suffers a rate of evaporation lower than in reality. This hypothesis is based on the fact that the model is able to reproduce approximately the location of rainfall maxima and their altitude (close to the peaks) and also the rainfall shadow in the leeward of the Pyrenees but not in the Andorran valleys.

Additionally, two fuzzy verification methods described in Ebert (2008) have been applied to QPF verification: the multi-event contingency table (Atger, 2001) and the conditional square root of RPS (Germann and Zawadzki, 2004). Results confirm the skill of the Meso-NH model precipitation forecast at $2.5 \mathrm{~km}$ in properly reproduce this heavy precipitation event over the Eastern Pyrenees - see Appendix A for details. These good results, obtained from both the qualitative and quantitative verification, ensure that the simulation is representative of the mesoscale environment that leads to this HPE. a)

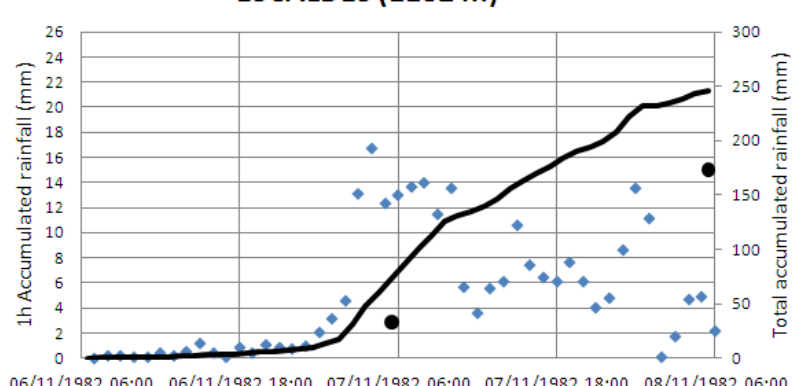

06/11/1982 06:00 06/11/1982 18:00 07/11/1982 06:00 07/11/1982 18:00 08/11/1982 06:00

b)

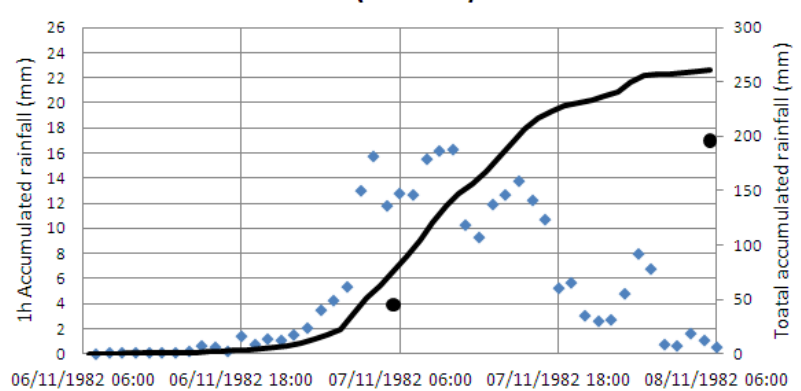

Fig. 8. Temporal evolution during the event of the $1 \mathrm{~h}$ simulated precipitation (blue dots, left axis in $\mathrm{mm}$ ), the total accumulated precipitation simulated by the model (black line, right axis in $\mathrm{mm}$ ) and observed rainfall accumulations from the beginning of the event (black dots, right axis in $\mathrm{mm}$ ) in two weather stations located in Andorra: (a) Escaldes (1182 m); (b) Ransol (1635 m). The location of these stations is shown in Fig. 5.

\section{Mesoscale analysis}

This section focuses on the analysis of the mesoscale factors leading to the triggering and maintenance of the precipitation for more than $30 \mathrm{~h}$ over the Pyrenees. To carry out the study, the results obtained from the 10 and $2.5 \mathrm{~km}$ simulations described in the previous section have been used. The analysis is divided in four parts, one for each of the chronological phases that have been identified by means of the synoptic environment description. In addition to the classical synoptic diagnostics at low and upper-levels, the water vapour flux at low levels has also been computed in order to characterise the moisture supply in each phase of the event. This additional diagnostic has been calculated such as a $3 \mathrm{~km}$-depth vertically integrated moisture flux:

$Q_{3}=\int_{0}^{z=3 \mathrm{~km}} \rho_{v} V_{\mathrm{h}} \mathrm{d} z$,

where $\rho_{v}$ is the specific humidity and $V_{\mathrm{h}}$ the horizontal wind. This diagnostic has also been used in other recent studies of HPE over the north-western Mediterranean area (e.g. Nuissier et al., 2008; Duffourg and Ducroq, 2011; Ricard et 

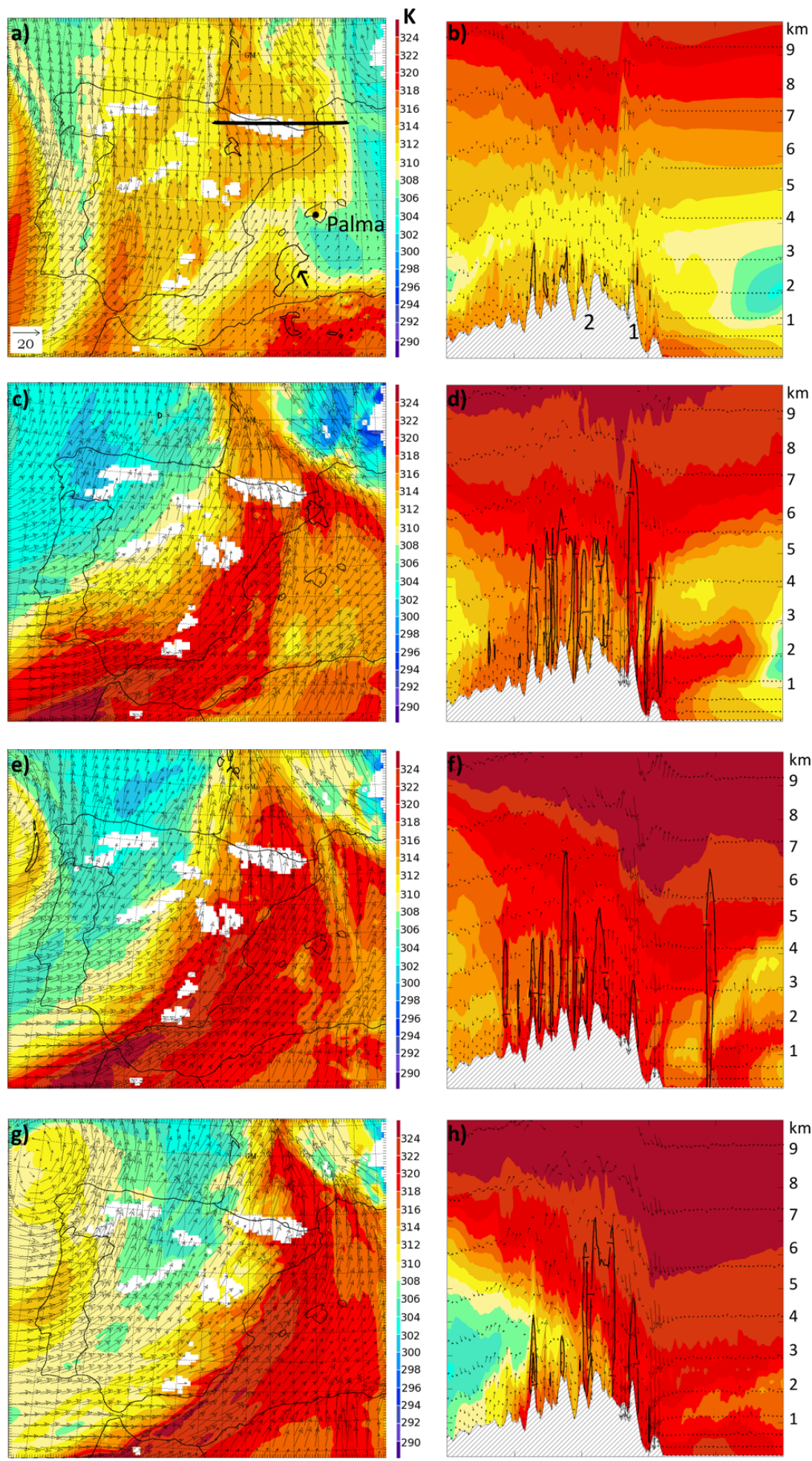

Fig. 9. Mesoscale evolution of different fields for each of episode phases: phase 1 at 12:00 UTC on 6 November 1982 (first row), phase 2 at 05:00 UTC on 7 November 1982 (second row), phase 3 at 12:00 UTC on 7 November 1982 (third row), phase 4 at 18:00 UTC on 7 November 1982 (fourth row). Left column (a, c, e, g) shows over the second domain $(10 \mathrm{~km}) 850 \mathrm{hPa}$ equivalent potential temperature (shaded, K), $850 \mathrm{hPa}$ wind (arrows, $\mathrm{m} \mathrm{s}^{-1}$; see panel a for reference vector) and CAPE computed for the most unstable parcel in the low levels $\left(500 \mathrm{~J} \mathrm{~kg}^{-1}\right.$ isocontour labelled and indicated with an arrow in (a). Right column (b, d, f, h) shows the vertical cross section of the equivalent potential temperature $(\mathrm{K})$ for the inner domain $(2.5 \mathrm{~km})$ along the axis labelled in panel (a) over the Pyrenees. Black isocontours indicate the total hydrometeor content greater than $1 \mathrm{~g} \mathrm{~kg}^{-1}$ and black arrows correspond to vertical velocity at different levels. 
al., 2012). The recent study from Ricard et al. (2012) presents a climatology of the mesoscale environment associated with heavy precipitation events which hit south-eastern France, as in the case considered here. According to the synoptic environment, this HPE belongs to the episodes classified as strong SW cyclonic flows in the Nuissier et al. (2011) classification. The mean moist flow integrated from 0 to $3 \mathrm{~km}$ for that circulation type calculated by Ricard et al. (2012) does not exceed $300 \mathrm{~kg} \mathrm{~m}^{-1} \mathrm{~s}^{-1}$ (see their Fig. 101).

Furthermore, in order to better understand the origin and dynamics of the air masses that feed the precipitation systems reproduced by the model over the Pyrenees, a series of backward trajectories have been computed during the second and third phases of the event. The backward trajectories of the selected lagrangian parcels inside the ascents $(4-7 \mathrm{~km})$ are performed by the lagrangian analysis tool of Gheusi and Stein (2002). The methodology followed in the analysis is similar to the one used in Duffourg and Ducrocq (2011): the air parcels are tracked backwards within the $2.5 \mathrm{~km}$ domain as long as they remain inside and at the latest till $4 \mathrm{~h}$ after the initial time; when the parcels go out of the $2.5 \mathrm{~km}$ domain, similar backward trajectories are performed in the $10 \mathrm{~km}$ domain, using the latest point of the parcel in the inner domain as a starting position. The evolution of the parcel water vapour mixing ratio along their trajectories is also examined in order to identify the role of the Mediterranean Sea as a local moisture source in this episode.

\subsection{Phase 1: first stage (06:00 UTC, 6 November 1982- 00:00 UTC, 7 November 1982)}

Before the episode, anticyclonic conditions and stable environment at low and upper levels prevailed especially over the Mediterranean area since the 27 October. These persistent conditions favoured the formation of a subsidence inversion around $1500 \mathrm{~m}$ and the accumulation of moisture at low levels generating a conditionally unstable Mediterranean air mass (Jansà, 1959; Ramis, 1995). The earlier hours of this stage, were characterized by low-level weak southerly winds over Catalonia which progressively shifted north-westward at 12:00 UTC over the surface induced by the anticyclonic conditions over Central Europe. This low-level maritime flow ensured the supply of relatively warm and moist air coming from the area located between Balearic Islands and Catalonia with CAPE values of $200 \mathrm{~J} \mathrm{~kg}^{-1}$ (Fig. 9a, $\Theta_{\mathrm{e}}$ around $313 \mathrm{~K}$ ). The atmospheric sounding observed in Palma de Mallorca 6 November at 12:00 UTC (Fig. 10) confirms this thermodynamic instability of the low level flow with LFC of $600 \mathrm{~m}$ (yellow part column), the presence of the subsidence inversion at $800 \mathrm{hPa}$ (blue part column) and clearly shows the wind shear between the surface and the rest of the vertical profile. These features are also present in the $\Theta_{\mathrm{e}}$ vertical cross section over a west-east axis along the Pyrenees (Fig. 9b), where the subsidence inversion and a layer of dry air (lower $\Theta_{\mathrm{e}}$ values) can be detected above
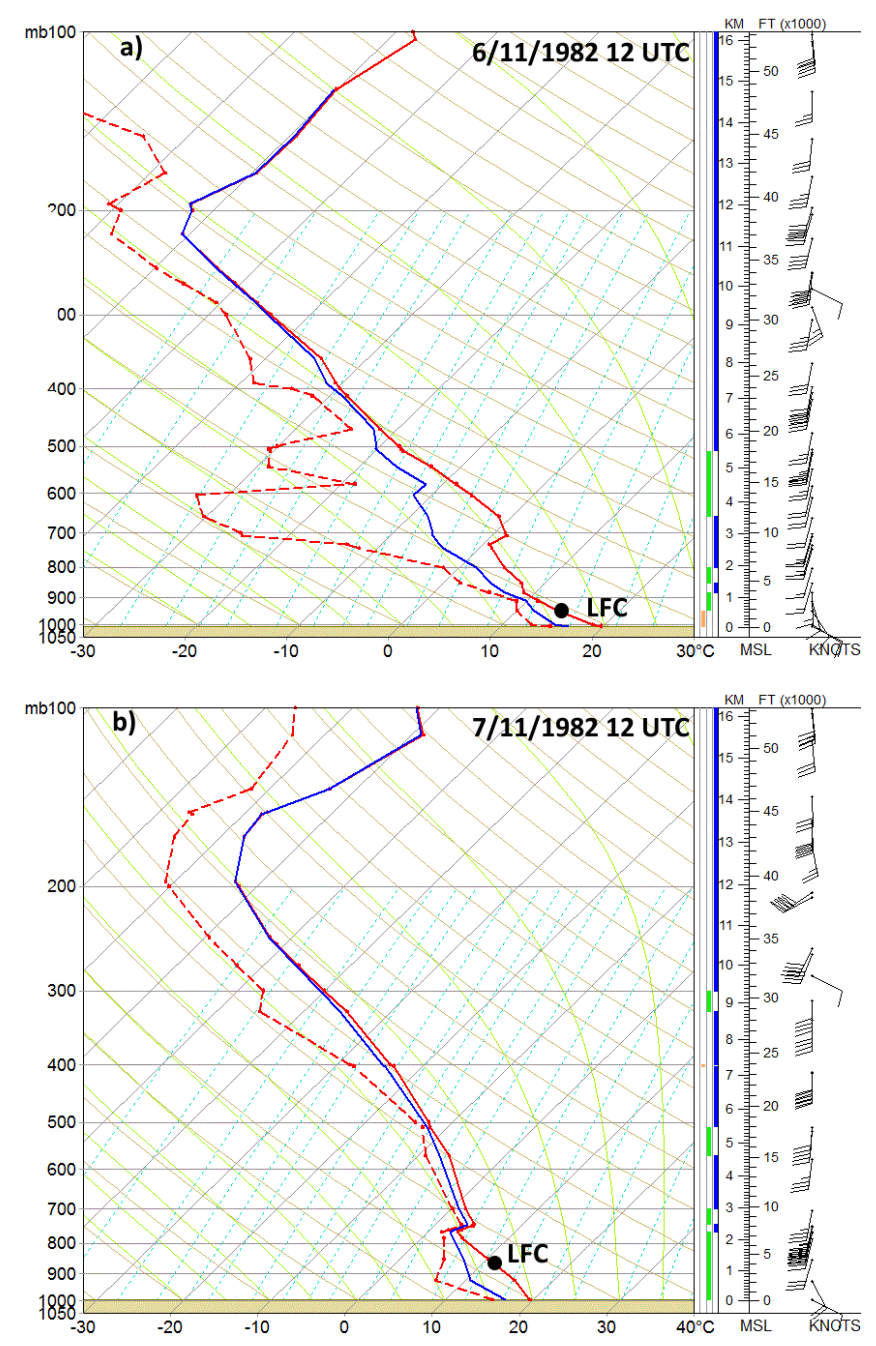

Fig. 10. Palma de Mallorca observed sounding: (a) 6 November 1982 at 12:00 UTC; (b) 7 November 1982 at 12:00 UTC. Vertical profiles of temperature $\left({ }^{\circ} \mathrm{C}\right.$, solid red line), dew point $\left({ }^{\circ} \mathrm{C}\right.$, dashed red line), wet-bulb potential temperature $\left({ }^{\circ} \mathrm{C}\right.$, solid blue line) and wind (knots) are represented. Right coloured vertical bars show the stability conditions for the whole vertical profile (labelled in $\mathrm{km}$ ). The stability correspondence for each colour is: blue stable; green - conditionally unstable; yellow - unstable. The level of free convection (LFC) is labelled as a black point.

$2000 \mathrm{~m}$ over the sea and the Pyrenees. In this initial stage the $3 \mathrm{~km}$ vertically integrated water vapour flux (Fig. 11a) was characterized by values lower than $200 \mathrm{~kg} \mathrm{~m}^{-1} \mathrm{~s}^{-1}$ over the Pyrenees, mostly concentrated in the lowest first kilometre. In Fig. 9a, over the north coast of Africa an area of elevated $\Theta_{\mathrm{e}}$ and conditionally unstable conditions with CAPE greater than $500 \mathrm{~J} \mathrm{~kg}^{-1}$ can be also distinguished. Along the Portugal coast another maximum of $\Theta_{\mathrm{e}}$ associated with an Atlantic moister flow $\left(400 \mathrm{~kg} \mathrm{~m}^{-1} \mathrm{~s}^{-1}\right)$ in the warm sector ahead of the cold front is identified. 

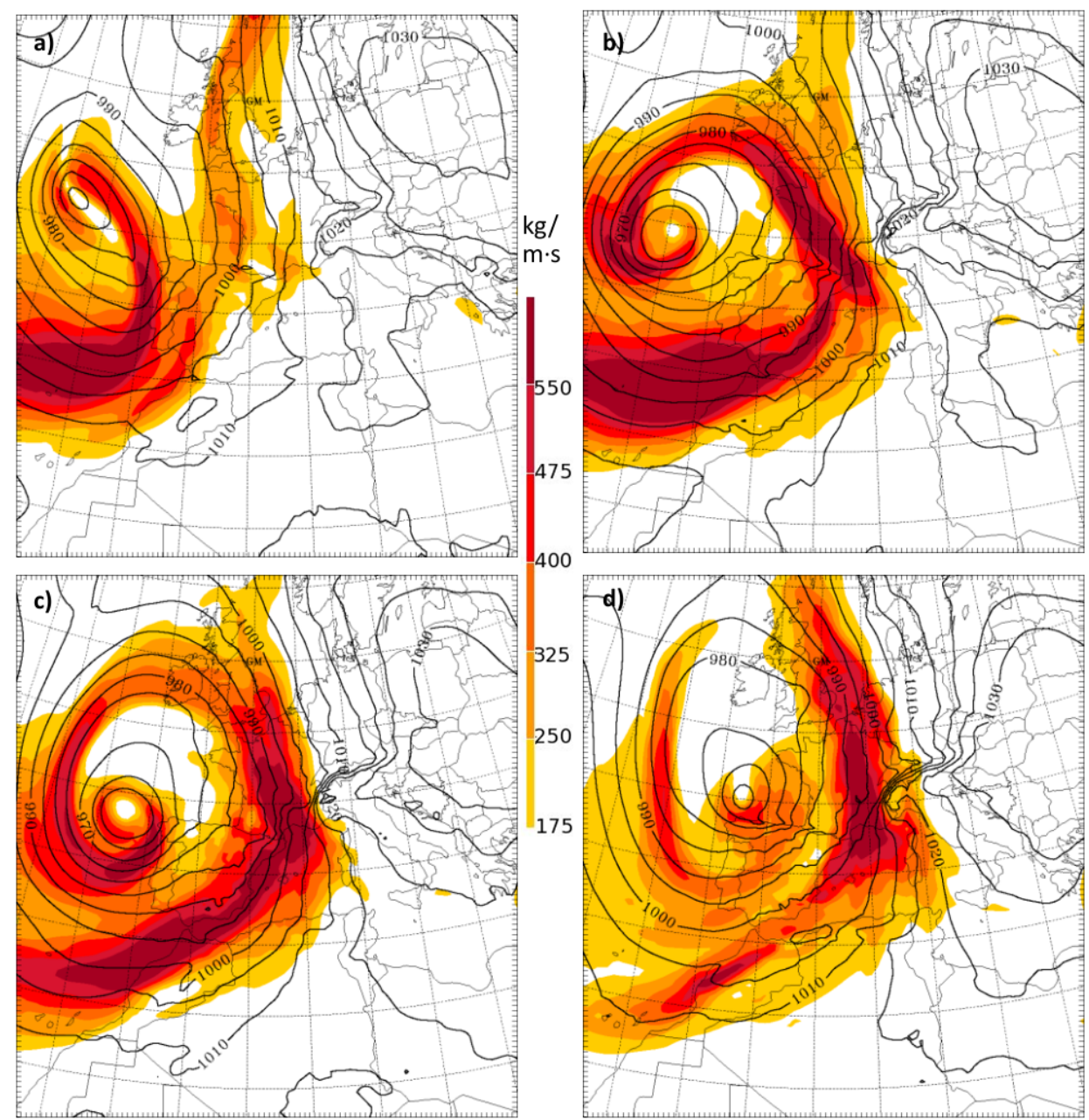

Fig. 11. Evolution of the water vapour flux integrated between the surface and $3 \mathrm{~km}$ of altitude (shaded colours, $\mathrm{kg} \mathrm{m}^{-1} \mathrm{~s}^{-1}$ ) and mean surface pressure (dark contours, hPa): (a) Phase 1: 12:00 UTC on 6 November 1982; (b) Phase 2: 04:00 UTC on 7 November 1982; (c) Phase 3: 12:00 UTC on 7 November 1982; (d) Phase 4: 00:00 UTC on 8 November 1982.

With the gradual increase of the pressure gradient over the Pyrenees, south-easterly winds are reinforced allowing the generation of the first precipitating clouds over the first foothills and the exposed south sides of the Pyrenees by means of the orographic uplift of the conditionally unstable air mass. Low level advection of warm air eroded the subsidence inversion and modified the lapse rate temperature profile. Figure 12 shows in violet shaded colour the areas at $1000 \mathrm{~m}$ with vertical velocities greater than $1 \mathrm{~m} \mathrm{~s}^{-1}$. Notice the elongated bands of vertical velocity just north of Andorra which can be associated with the mountain wave generation downstream of the Pyrenees. The first orographic clouds are identified in the cross-vertical section (Fig. 9b), where the total hydrometeor content exceeding $1 \mathrm{~g} \mathrm{~kg}^{-1}$ (solid black line) is represented. The rainfall accumulated during this initial stage (Fig. 13a) is characterized by light and persistent orographic induced precipitation $(<50 \mathrm{~mm})$ developed in a still conditionally unstable airflow under anticyclonic conditions.

\subsection{Phase 2: warm front affecting the Pyrenees (00:00- 08:00 UTC, 7 November 1982)}

The second stage of the episode began the 7 November 1982 (00:00 UTC), when the warm air mass located over the Balearic Islands and previously detected in phase 1 over North Africa (a warm source region) was advected northwards, organized as a west-east frontal band following the SE coastline of the Iberian Peninsula. The south-easterly wind component still present at low levels allowed this warm unstable flow with CAPE values greater than $500 \mathrm{~J} \mathrm{~kg}^{-1}$ to penetrate into Catalonia. Figure 9c shows the west-east band of high $\Theta_{\mathrm{e}}$ affecting the Eastern Pyrenees at 05:00 UTC on 7 November 1982 and Fig. 11b indicates that the $Q_{3}$ associated with this air mass is more important than previous stage $\left(>400 \mathrm{~kg} \mathrm{~m}^{-1} \mathrm{~s}^{-1}\right)$. Behind this first warm front, the strong south-westerly flow induced by the Atlantic cyclone was established over the entire Iberian Peninsula. The warm conveyor belt appears in Fig. 9c as a wide stream of elevated 
Table 2. Approximate water vapour mixing ratios of the parcels along their pathways over the Mediterranean Sea.

\begin{tabular}{llrrrr}
\hline $\begin{array}{l}\text { Precipitation } \\
\text { structure }\end{array}$ & Level & $\begin{array}{r}\text { Final WV } \\
\text { mixing ratio }\end{array}$ & $\begin{array}{r}\text { Initial WV } \\
\text { mixing ratio }\end{array}$ & $\begin{array}{r}\text { WV mixing ratio } \\
\text { gained from the sea }\end{array}$ & $\begin{array}{r}\text { Time above } \\
\text { the sea }\end{array}$ \\
\hline \multirow{2}{*}{ PHASE 2 - Andorra } & lowest $1000 \mathrm{~m}$ & $10 \mathrm{~g} \mathrm{~kg}^{-1}$ & $8.5 \mathrm{~g} \mathrm{~kg}^{-1}$ & $1.5 \mathrm{~g} \mathrm{~kg}^{-1}$ & $9 \mathrm{~h}$ \\
& $1000-2000 \mathrm{~m}$ & $7 \mathrm{~g} \mathrm{~kg}^{-1}$ & $4.5 \mathrm{~g} \mathrm{~kg}^{-1}$ & & - \\
\multirow{3}{*}{ PHASE 2 - Canigo } & lowest $1000 \mathrm{~m}$ & $8-11 \mathrm{~g} \mathrm{~kg}^{-1}$ & $8 \mathrm{~g} \mathrm{~kg}^{-1}$ & $2 \mathrm{~g} \mathrm{~kg}^{-1}$ & $12 \mathrm{~h}$ \\
& $1000-2000 \mathrm{~m}$ & $7 \mathrm{~g} \mathrm{~kg}^{-1}$ & $4-7 \mathrm{~g} \mathrm{~kg}^{-1}$ & $2 \mathrm{~g} \mathrm{~kg}^{-1}$ & $12 \mathrm{~h}$ \\
PHASE 3 - Andorra & lowest $1000 \mathrm{~m}$ & $9-10 \mathrm{~g} \mathrm{~kg}^{-1}$ & $6.5 \mathrm{~g} \mathrm{~kg}^{-1}$ & $3.5 \mathrm{~g} \mathrm{~kg}^{-1}$ & $8 \mathrm{~h}$ \\
& $1000-2000 \mathrm{~m}$ & $7.8 \mathrm{~g} \mathrm{~kg}^{-1}$ & $7.2 \mathrm{~g} \mathrm{~kg}^{-1}$ & $1 \mathrm{~g} \mathrm{~kg}^{-1}$ & - \\
PHASE 3 - Canigo & lowest $1000 \mathrm{~m}$ & $9 \mathrm{~g} \mathrm{~kg}^{-1}$ & $6 \mathrm{~g} \mathrm{~kg}^{-1}$ & $3 \mathrm{~g} \mathrm{~kg}^{-1}$ & $10 \mathrm{~h}$ \\
& $1000-2000 \mathrm{~m}$ & $7-8 \mathrm{~g} \mathrm{~kg}^{-1}$ & $7-8 \mathrm{~g} \mathrm{~kg}^{-1}$ & $1 \mathrm{~g} \mathrm{~kg}^{-1}$ & $10 \mathrm{~h}$ \\
\hline
\end{tabular}

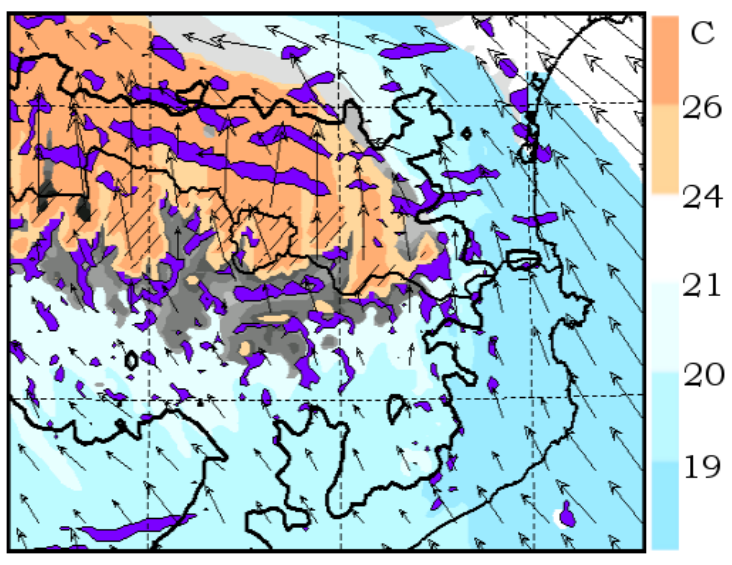

Fig. 12. Wind at $10 \mathrm{~m}$ a.g.l. (arrows, $\mathrm{ms}^{-1}$ ), virtual potential temperature at $850 \mathrm{hPa}$ (shaded colours, ${ }^{\circ} \mathrm{C}$ ), and areas with updrafts greater than $1 \mathrm{~m} \mathrm{~s}^{-1}$ at $1000 \mathrm{~m}$ (in violet) on the 6 November 1982 at 16:00 UTC. The $500 \mathrm{~m}$ topography is shown as a black solid contour and dashed areas correspond to regions above $2000 \mathrm{~m}$.

$\Theta_{\mathrm{e}}$ passing through the Gibraltar strait due to the presence of the Atlas range (Morocco) and following the Spanish Mediterranean Coast. The $Q_{3}$ also evidences the remarkable water content of this Atlantic flow $\left(>400 \mathrm{~kg} \mathrm{~m}^{-1} \mathrm{~s}^{-1}\right)$ with a maximum of $550 \mathrm{~kg} \mathrm{~m}^{-1} \mathrm{~s}^{-1}$ in front of Valencia (Fig. 11b).

Figure 14 represents the temporal evolution of the simulated radar reflectivities at an altitude of $2.5 \mathrm{~km}$ from 02:00 to 06:00 UTC (7 November 1982). Although widespread precipitation is simulated over the Pyrenees and Catalonia, a maximum can be clearly identified as a non-stationary convective line associated with the warm front moving eastward. The total hydrometeor content close to Canigo massif (Fig. 9d) has an important vertical dimension of the precipitating cloud $(7 \mathrm{~km})$ compared to the other areas in the Pyrenees $(5 \mathrm{~km})$, which indicates the convective character of the precipitation in this area. This is consistent with the meteorological observations described in Sect. 2.2 that thunderstorms were observed in the Languedoc-Roussillon region. The backwards trajectories taken in the convective cells over Canigo at 05:00 UTC (Fig. 15) show the low-level convergence of three branches due to the channelling of the southerly low level flows (below $1000 \mathrm{~m}$ ) over the eastern edge of the Pyrenees. The parcels reaching $7 \mathrm{~km}$ in the vertical cross section also reveal the distinct uplifts suffered by parcels coming from higher levels $(1-2 \mathrm{~km})$ in the southerly flow. These ascents are mainly due to the interaction of the warm front with the Pyrenees (orographic forcing) as it can be seen in the backward trajectory extension of this branch over $10 \mathrm{~km}$ domain where the North African origin of the parcels is identified. Table 2 shows the evolution of the water vapour content along the pathway over the Mediterranean Sea. In this case, all parcels take around $12 \mathrm{~h}$ to reach the Pyrenees evidencing the intense low level winds which efficiently advected the conditionally unstable moist flow $\left(\sim 8 \mathrm{~g} \mathrm{~kg}^{-1}\right)$. Unlike the low level parcels progressively increment their vapour mixing ratio during their transport over the Mediterranean basin, parcels above $1000 \mathrm{~m}$ keep its water vapour content almost constant and gain less than $2 \mathrm{~g} \mathrm{~kg}^{-1}$ in the previous $2 \mathrm{~h}$ before reaching land. This organized convection had some similarities with the MCS described by Nuissier et al. (2008) during the catastrophic Aude event (their Figs. 7b, $19 \mathrm{c}$ and 24a).

Over the west border of Andorra from 03:00 UTC to 04:00 UTC there is a secondary maximum of reflectivity (Fig. 14a and b). According to the precipitation estimated by the terrain analysis (Fig. 5), this secondary maximum could contribute to explain the extreme rainfall intensities estimated in the west of Andorra. Based on the simulation's results this location of the maximum seems to be favoured by an area of moisture convergence at low levels. The southerly winds that affected the Pre-Pyrenees created a local south-easterly circulation probably to flow around the Port del Compte range (just south of Cadi) and converge with the dominant south flow along the Segre Valley (south of Andorra). For this precipitation system, the backward trajectories confirm the channelling in the Segre Valley of a southerly flow coming from the Gibraltar strait as the $2.5 \mathrm{~km}$ domain shows (Fig. 15). The vertical structure was 

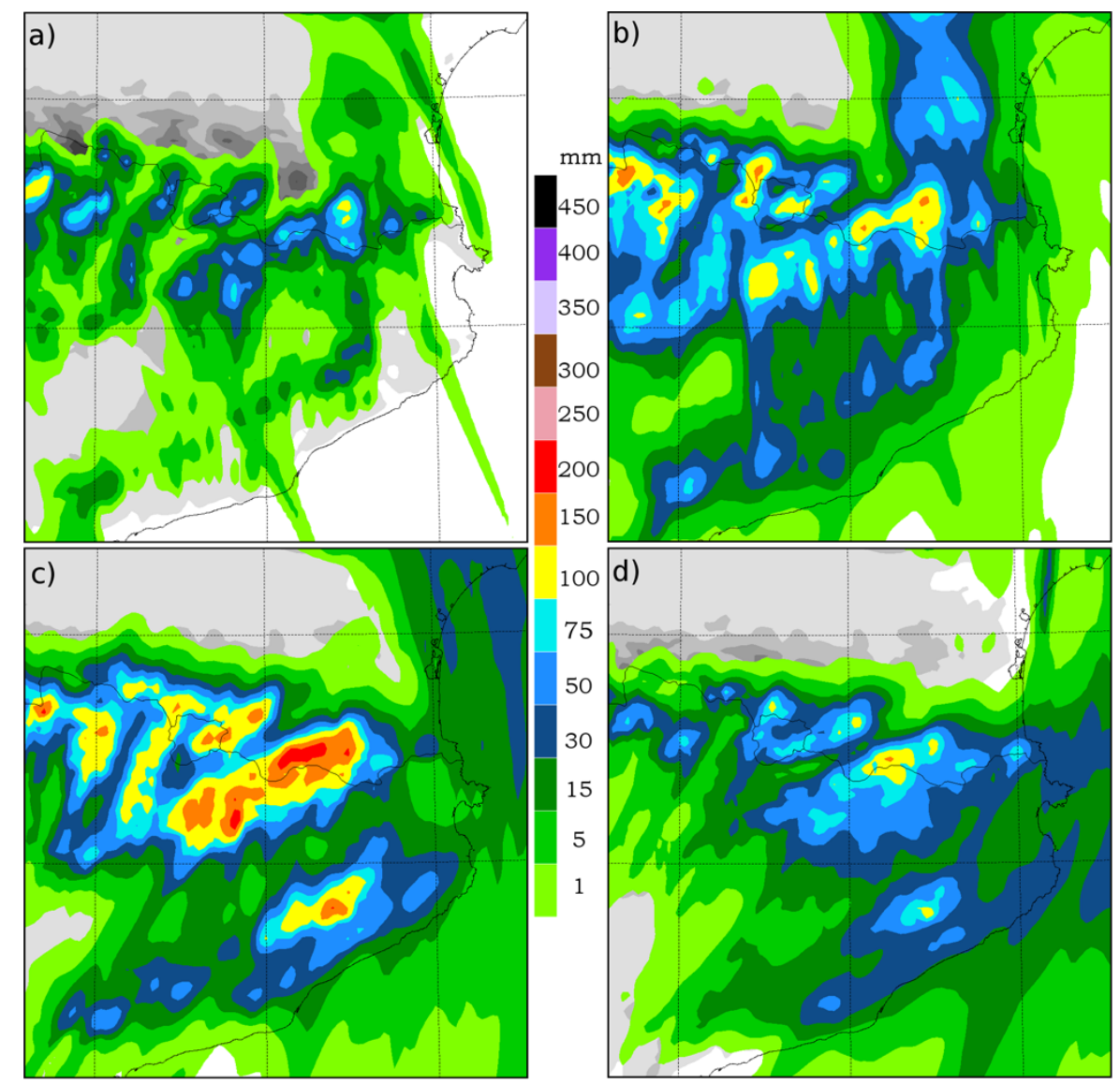

Fig. 13. Accumulated precipitation $(\mathrm{mm})$ simulated for each of the episode phases: (a) Phase 1: from 06:00 UTC on 6 November to 00:00 UTC on 7 November 1982; (b) Phase 2: from 00:00 UTC on 7 November to 08:001 UTC on 7 November 1982; (c) Phase 3: from 08:00 UTC on 7 November to 18:00 UTC on 7 November 1982; (d) Phase 4: from 19:00 UTC on 7 November to 06:00 UTC on 8 November 1982.

less developed than in the Canigo region $(5 \mathrm{~km})$, but clearly shows the $1000-2000 \mathrm{~m}$ as a feeding layer of this convective cell. As in the previous structure, the parcels above $1000 \mathrm{~m}$ stayed up to $11 \mathrm{~h}$ over the Mediterranean Sea and did not modify its moisture content $\left(4.5 \mathrm{~g} \mathrm{~kg}^{-1}\right)$ along its pathway. It is over land when parcels descended hundreds of metres and reached saturation mainly due to mixing processes with moister low level flow coming from North Africa $\left(10 \mathrm{~g} \mathrm{~kg}^{-1}\right)$ as the yellow parcel shows.

The rainfall accumulations during the second phase (Fig. 13b) are more intense than in the previous stage due to the arrival from North Africa of a warm and moister air mass. The accumulation presents two maxima which match the limits of the Pre-Pyrenees: one over the western border of Andorra and the other over the eastern extreme of the Pyrenees. The imprint of the warm front is clearly identified in the second case in a north-south band of intense precipitation. The rainfall underestimation over the Roussillon region could be attributed to the lesser stationarity of the simulated convective system which developed over the mountains and propagated north-eastward. This second phase governed by cyclonic conditions is characterized by the interaction of the warm front with the Pyrenees, where the relief as well as acting as a lifting triggering mechanism also modulated its advance, channelling the unstable air mass and generating low level convergence areas.

\subsection{Phase 3: moist conveyor belt (08:00-18:00 UTC, 7 November 1982)}

On the morning of 7 November, the third phase of the episode started. It was characterized by steady precipitation leading to extreme rainfall accumulations (Fig. 13c) over the Pyrenees, following the mountain range configuration and affecting the most exposed sides to the southerly flow: the SW-NE orientation of the Pre-Pyrenees and the S-N valleys axis. The simulated reflectivity evolution from 09:00 to 18:00 UTC on 7 November 1982 represented in Fig. 16 evidences the stationary and continuous regeneration of the precipitating cells as well as the eastward evacuation over the sea of the convective line developed in the previous phase. Furthermore, over the first foothills close to the coast 
a) $7 / 11 / 198203$ UTC

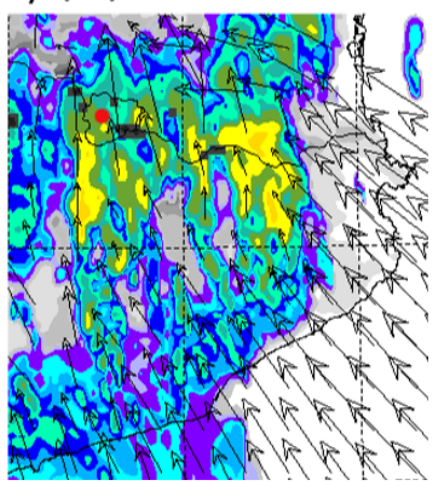

b) $7 / 11 / 198204$ UTC

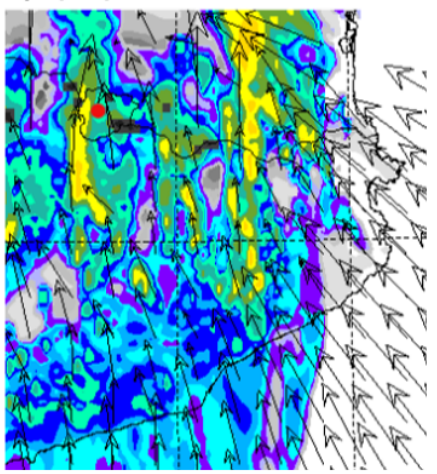

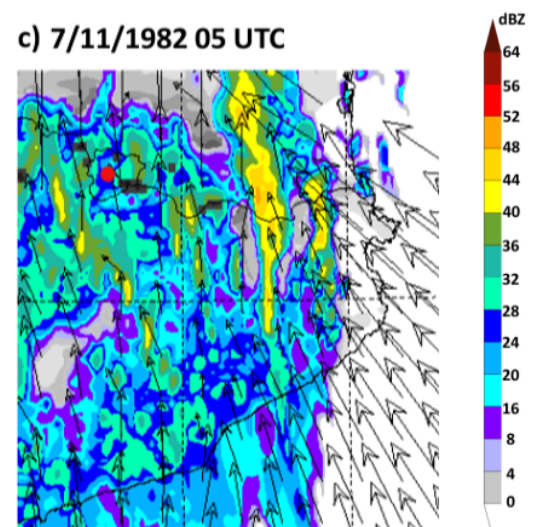

Fig. 14. Evolution during phase two of the simulated reflectivity at $2500 \mathrm{~m}$ (shaded colours, dBZ) and $10 \mathrm{~m} \mathrm{a.g.1.} \mathrm{wind} \mathrm{(arrows,} \mathrm{m} \mathrm{s}^{-1}$ ).
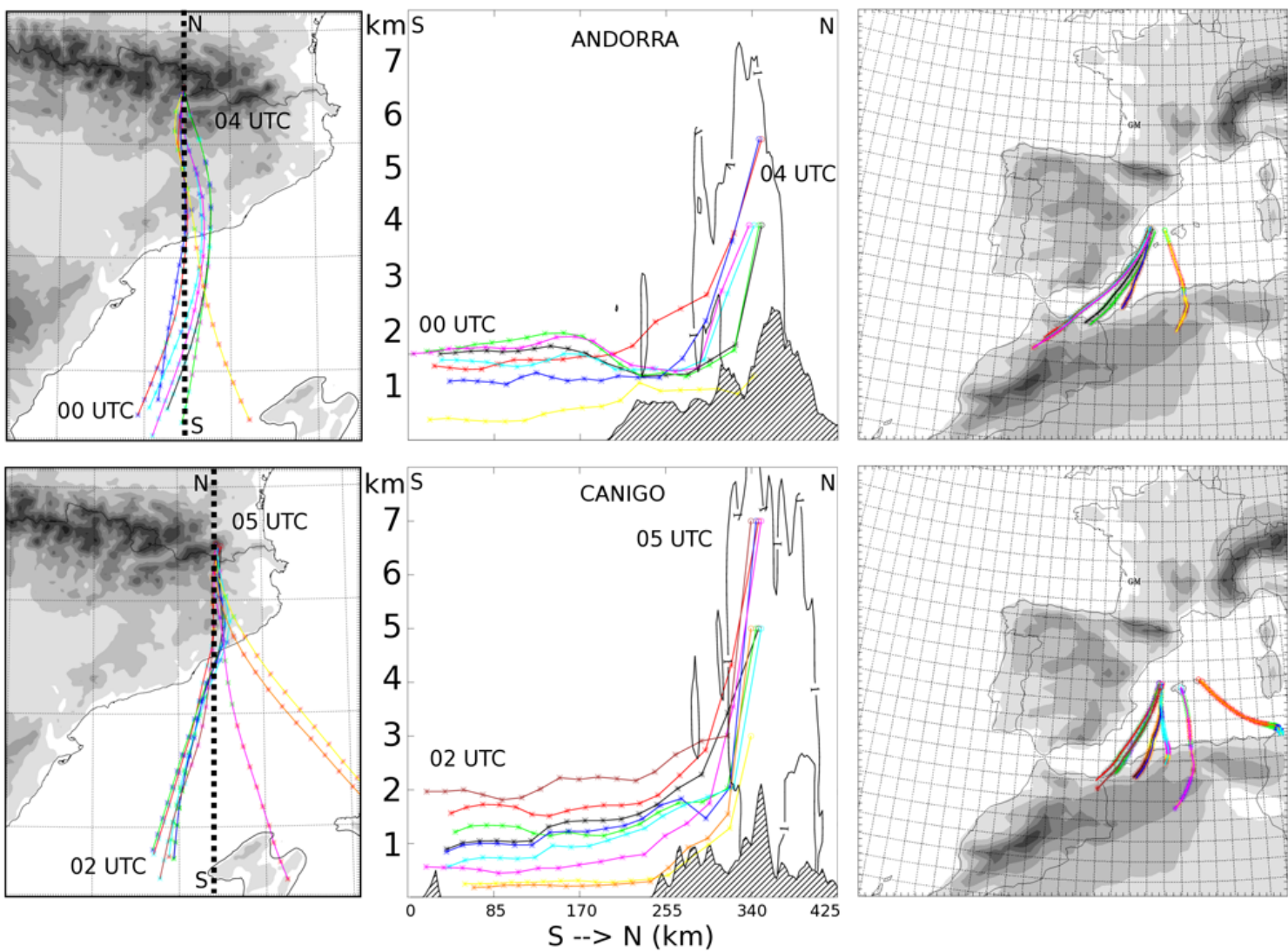

Fig. 15. Backward trajectories of some air parcels taken in the upper part of precipitating systems simulated over a $2.5 \mathrm{~km}$ domain projected in an horizontal plane (left column) in Andorra (top panels) and Canigo massif (bottom panels). The backward trajectories are also projected on a vertical cross section (middle column) which follows the line SN displayed on the left panels. Right column shows the extension of the backward trajectories over the $40 \mathrm{~km}$ domain. Orography is superimposed in grey scale as in Fig. 1 and as a hatched area for the vertical cross sections.

relatively high reflectivity values are also simulated which clearly contrast with the weak values present in the valleys and the central depression of Catalonia.

The long-lasting synoptic blocking and the mature stage of the Atlantic extratropical cyclone during this phase were reflected in the mesoscale environment through the persistent highest wind speeds of the south-westerly cyclonic flow in the entire vertical profile. At 12:00 UTC, 7 November 1982, the wide moist conveyor belt impinging directly on the Pyrenees can be distinctly identified in 
a) $7 / 11 / 198209$ UTC

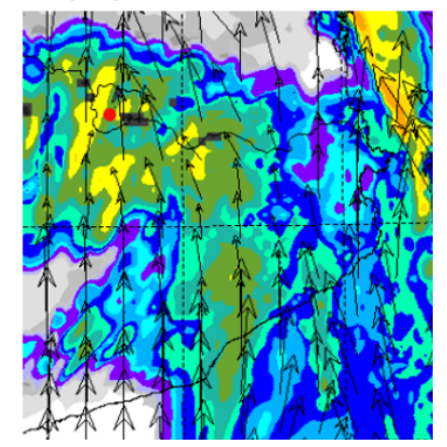

b) $7 / 11 / 198212$ UTC

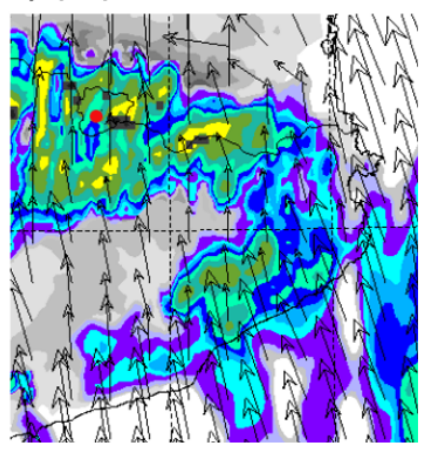

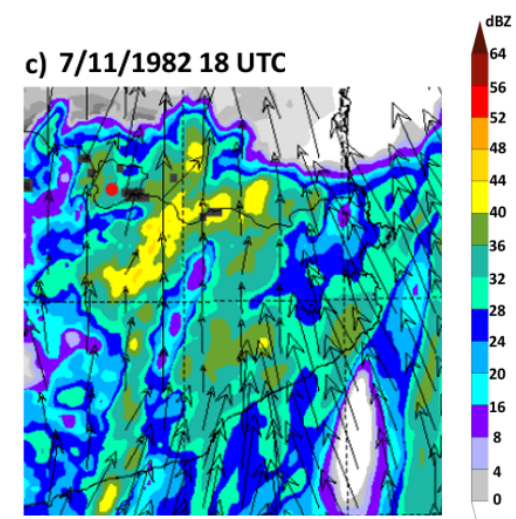

Fig. 16. Evolution during phase three of the simulated reflectivity at $2500 \mathrm{~m}$ (shaded colours, dBZ) and $10 \mathrm{~m}$ a.g.1. wind (arrows, $\mathrm{m} \mathrm{s}^{-1}$ ).
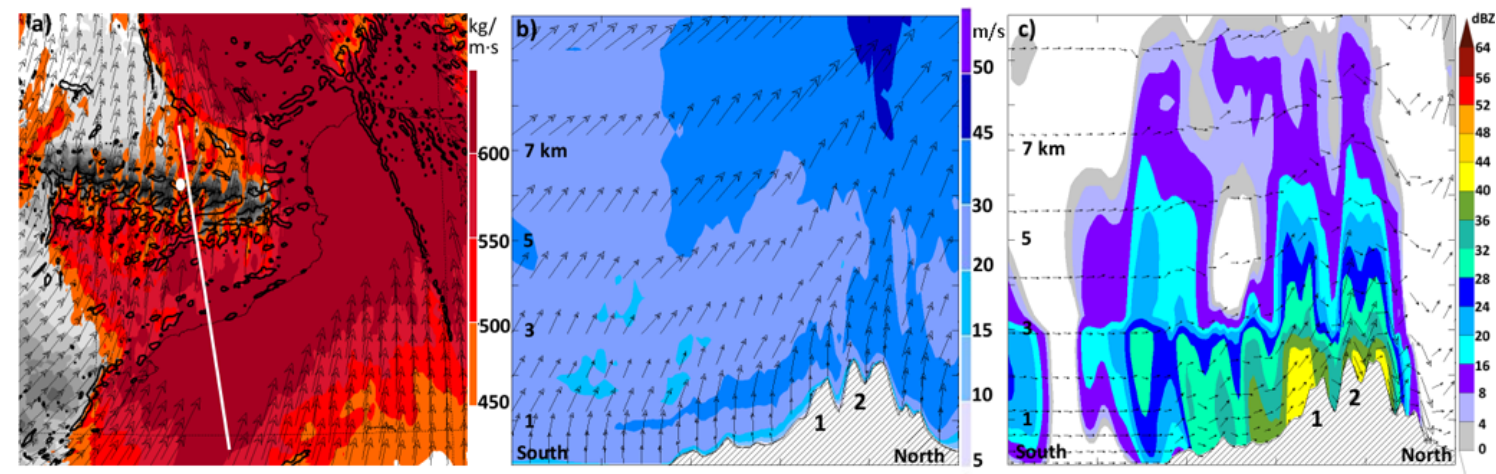

Fig. 17. (a) Moisture water vapour flux vertically integrated from surface to $3 \mathrm{~km}$ (shaded colours, $\mathrm{kg} \mathrm{m}^{-1} \mathrm{~s}^{-1}$ ) and simulated updrafts at $1500 \mathrm{~m}$ (black contours, $>1 \mathrm{~m} \mathrm{~s}^{-1}$ ) during the third phase at 12:00 UTC on 7 November 1982. The south-north axis indicates the vertical cross section at 16:00 UTC on 7 November 1982 shown in panels: (b) horizontal wind speed and direction (shaded colours and arrows, $\mathrm{m} \mathrm{s}^{-1}$ ); (c) Simulated reflectivity (shaded colours, dBZ) and vertical wind (1. Cadi massif, 2. Andorra).

the potential temperature field at $850 \mathrm{hPa}$ (Fig. 9e), with values exceeding $316 \mathrm{~K}$ but unlike the second stage the air mass had lower values of CAPE $\left(<500 \mathrm{~J} \mathrm{~kg}^{-1}\right)$ and elevated LFC around $1200 \mathrm{~m}$ (Fig. 10b). The west-east vertical cross section over the Pyrenees (Fig. 9f) shows the vertical extent of this warm and moist layer (high $\Theta_{\mathrm{e}}$ within the first $4 \mathrm{~km}$ along the mountain axis between Andorra and Canigo massif). The total water content of hydrometeors (represented as black contours $>1 \mathrm{~g} \mathrm{~kg}^{-1}$ ) reveals the generation of vertically developed precipitating cores over the relief. In the eastern extreme, over the sea, the vertical structure of the warm front and its convective associated line can be identified. It is during this stage, that the low level water content flux achieves its greatest intensity exceeding the $550 \mathrm{~kg} \mathrm{~m}^{-1} \mathrm{~s}^{-1}$ during the entire period (Fig. 11c). This exceptional moist flow persisted approximately $10 \mathrm{~h}$ perpendicular to the Pyrenees, supplying a long-lasting precipitation system. Vertical velocities greater than $1 \mathrm{~m} \mathrm{~s}^{-1}$ at $1500 \mathrm{~m}$ represented in Fig. 17a clearly identify the orography as triggering mechanism of convective cells and its continuous regeneration while the above mentioned very moist flow persisted. Despite over other mountainous areas above $1000 \mathrm{~m}$ on the Catalan coast (Montseny) there were also vertical motions, it was over the Pyrenees where convective cell generation was more efficient because the orographic uplift was enough to reach the LFC and trigger precipitating cells. As it can be seen in the vertical cross section at 16:00 UTC (Fig. 17b) surface winds reached values of $15 \mathrm{~m} \mathrm{~s}^{-1}$ persisting more than $10 \mathrm{~h}$. Furthermore, a distinct low level jet (LLJ) of $30 \mathrm{~m} \mathrm{~s}^{-1}$ around $1500 \mathrm{~m}$, favouring strong vertical wind shear, generated a layer of negative horizontal vorticity. This layer interacted with the orography contributing to enhance the upward motion on the south slopes of the Pyrenees. The vertical reflectivity profile along a south-north axis over Andorra and Catalonia (Fig. 17c) evidences the south slope location of the most intense and vertically developed precipitation structures where the most distinct upward motions represented by the arrows took place. Note the intense downslope flow in the north slope of the Pyrenees causing the rapid evaporation of the precipitating system due to the strong adiabatic warming. This effect can also be detected in the Segre Valley located between Cadi range and Andorra, where rainfall accumulation was less important. 

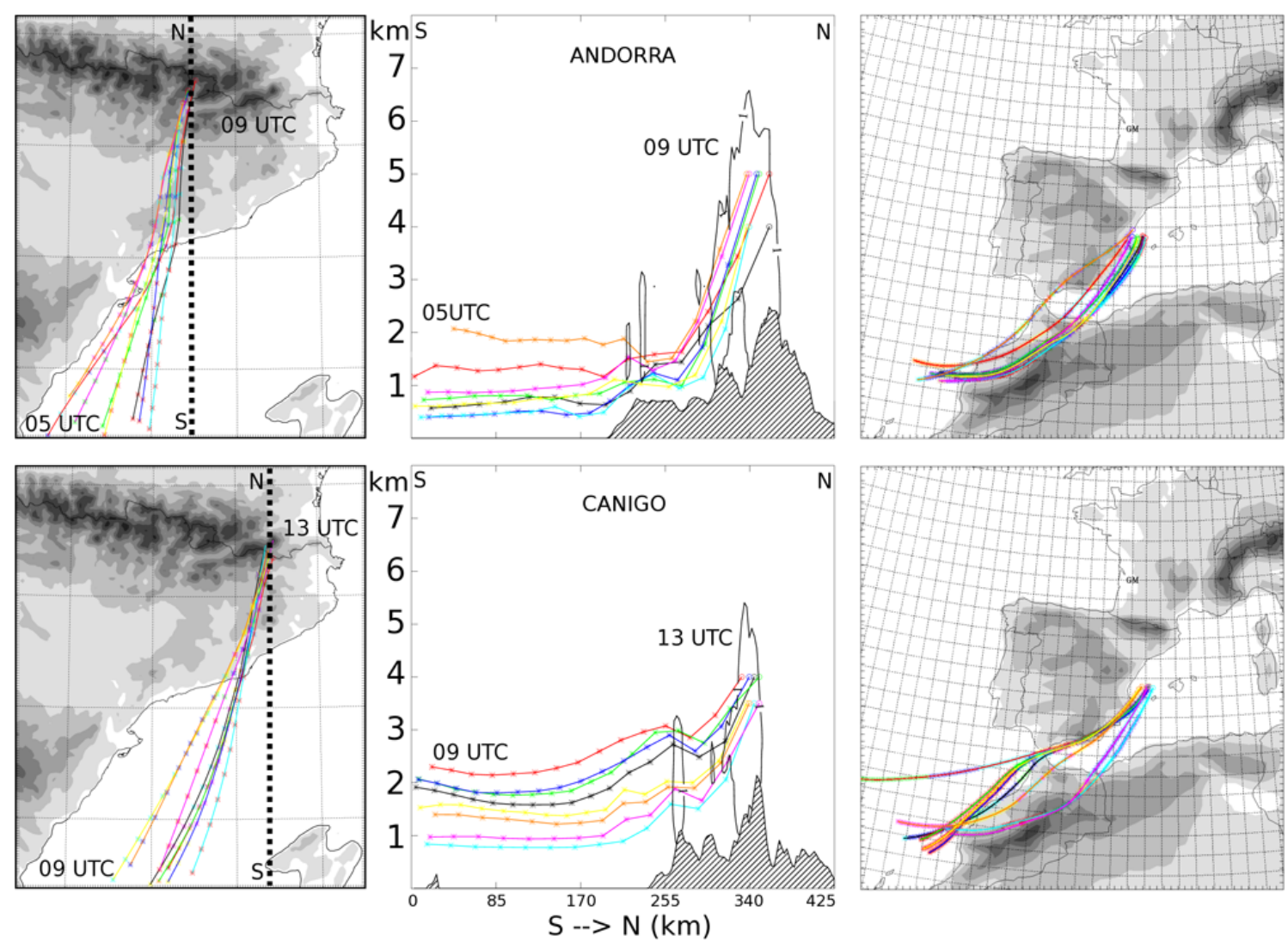

Fig. 18. Same as Fig. 15, but for the two regions during phase 3: Andorra (top panels) and Canigo (bottom panels).

The backward trajectories computed during this phase are represented in Fig. 18. Both precipitation systems selected over Andorra and Canigo were fed by a unique branch coming from Gibraltar strait and advanced north-eastward along the Spanish coast. Due to the cyclonic winds strengthening during this phase, parcels spent less than $10 \mathrm{~h}$ over the sea. It appears from the vertical cross section that parcels were directly uplifted by orographic forcing over the Pyrenees and it low-level convergence did not exist. Parcels taken in the Andorran updrafts (5-4 km) were mostly situated below $1000 \mathrm{~m}$. However, cells over Canigo region were less developed $(5 \mathrm{~km})$ and fed by parcels mainly situated inside the LLJ (between 1000 and $2000 \mathrm{~m}$ ). The moisture transport and the amount gained from the Mediterranean Sea are clearly conditional to its initial content and the level where the parcel was located. As shown in Table 2, the elevated initial water content before entering the Gibraltar region $\left(>6 \mathrm{~g} \mathrm{~kg}^{-1}\right)$ highly limited the contribution of the Mediterranean Sea: parcels below $1000 \mathrm{~m}$ gained around $3 \mathrm{~g} \mathrm{~kg}^{-1}$, and the ones above this level almost did not modify their content $\left(1 \mathrm{~g} \mathrm{~kg}^{-1}\right)$.

From the fact that stationary convective cells were simulated over the Pyrenees during this stage, and there was no upstream propagation of the convective systems, it could be inferred that the system did not produce any cold pool propagating away from the ridge. In the vertical profile of $\Theta_{e}$ (Fig. 9f) a mixed convective layer, which acts to increase $\Theta_{\mathrm{e}}$ at mid-levels and decrease in the lower levels, can be identified as in the idealized simulations of strong conditionally unstable flow over a mountain ridge performed by Migletta and Rotunno (2009) (their Fig. 7c). This result is consistent with the idealized works of Bresson et al. (2012) or Migletta and Rotunno (2009), where they prove that for strong mid-level winds $\left(20 \mathrm{~m} \mathrm{~s}^{-1}\right)$ precipitation is reinforced over the mountains and the presence of a cold pool it is most unlikely because there is no time (from the Lagrangian point of view) for evaporation to have a significant cooling effect on the upstream temperature field. Moreover, if moist advection at low levels or highest $\Theta_{\mathrm{e}}$ values at $850 \mathrm{hPa}$ affect an extended area, then the rainfall will be widespread instead of focused on a particular location. In this case study, precipitation was all over the Eastern Pyrenees.

During this third phase the event reached its highest intensity due to the steady interaction of the warm and moist conveyor belt ahead of the cold front with the Pyrenees. 
a) $7 / 11 / 198222$ UTC

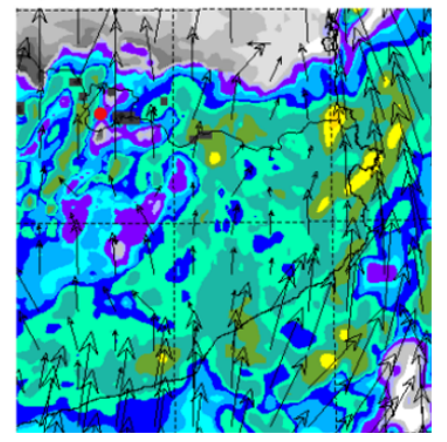

b) $8 / 11 / 198201$ UTC

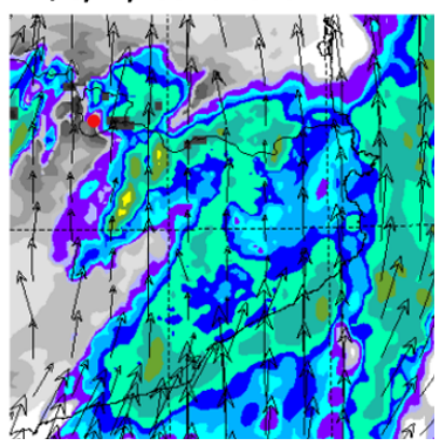

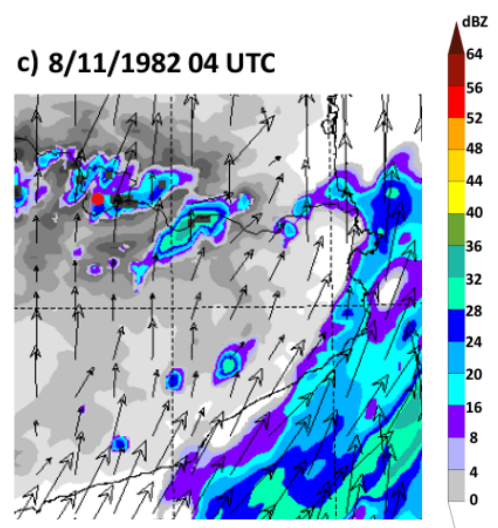

Fig. 19. Evolution during phase four of the simulated reflectivity at $2500 \mathrm{~m}$ (shaded colours, dBZ) and $10 \mathrm{~m}$ a.g.l. wind (arrows, $\mathrm{m} \mathrm{s}^{-1}$ ).

\subsection{Phase 4: cold front passing over Andorra and dissipation (18:00 UTC, 7 November 1982)}

The last phase starts at 18:00 UTC on 7 November, when the omega blocking pattern identified in the synoptic conditions weakened due to the eastward displacement of the upper-level ridge and the deep Atlantic low started to decay. The cold frontal surface which remained stationary in front of the Galician coast during the previous stages eventually progressed north-eastward approaching Andorra. Figure 9g shows the strong gradient in the $\Theta_{\mathrm{e}}$ field along a north-south axis which delimited the cold front edge over the Pyrenees. The characteristic shape of the leading edge of the cold-frontal surface is also identified in the vertical cross section (Fig. 9h), where well-developed convective cells are favoured by the distinct uplift triggered over the boundary of the two different air masses. The total content of hydrometeors exceeding $1 \mathrm{~g} \mathrm{~kg}^{-1}$ shows the vertical dimension of the convective cells over Andorra reaching $7 \mathrm{~km}$. At the same time its progressive propagation eastward evacuated moist and warm air, which was still feeding the upslope flow over the easternmost Pyrenees. As a result, one of the main ingredients that allowed the steady cell development over the mountain ridge decayed and precipitation started to weaken as it can be observed in the temporal reflectivity evolution (Fig. 19). During the night of 8 November, the exceptional moist level flux that impinged perpendicularly on the Pyrenees during the previous phase was evacuated over the Mediterranean Sea (Fig. 11d) and affected the southern French coast and the Massif Central where the most intense convective cells developed. During this last phase characterized by more dynamic atmospheric conditions, rainfall accumulations distinctly decreased over Andorra and the rest of the NE of the Iberian Peninsula (Fig. 13d).

\section{Conclusions}

The historical catastrophic HPE recorded in Andorra from 6 to 8 November 1982 has been analyzed in detail and, for the first time, using mesoscale model simulations at $2.5 \mathrm{~km}$ horizontal resolution with the French Meso-NH model. The analysis has a twofold objective: to describe the synoptic environment in which the HPE developed and to identify the mesoscale mechanisms that lead to steady rainfall over the Eastern Pyrenees as well as the features of the moisture inflow feeding the precipitation systems which were fairly well reproduced by the model.

At synoptic-scale the event was characterized by a deep Atlantic cyclone which generated a strong southerly flow over the Iberian Peninsula. The presence of low and upper level anticyclonic conditions installed over Central Europe favoured a slow evolving synoptic environment. Based on the evolution of the extratropical cyclone, its structure and the interaction with Pyrenees, four distinct phases have been distinguished during the event. The earlier stage developed in a still anticyclonic environment was characterized by light and persistent orographic rainfall favoured by a conditionally unstable airstream impinging on the mountains. During the second phase, the rainfall accumulations were intensified due to the interaction of warm and moist air mass coming from North Africa with the Eastern Pyrenees. The gradual strengthening of the cyclonic conditions contributed to the fast advection of this African warm front and the generation of a low level unstable flow with CAPE and low-level moisture content more important than the initial stage, especially in the eastern edge of the Pyrenees. The third phase is the most intense in terms of rainfall accumulations as a consequence of the stationary synoptic conditions and the highest intensities of the south-westerly cyclonic flow generating a LLJ. As a result, the Atlantic warm and moist conveyor belt impinged over the whole Eastern Pyrenees more than $10 \mathrm{~h}$. As in the Aude (1999) case reported in Nuissier et al. (2008), the low CAPE 
values of this lasting flux seems to be counterbalanced by large moisture fluxes $\left(550 \mathrm{~kg} \mathrm{~m}^{-1} \mathrm{~s}^{-1}\right)$. During the last phase, rainfall accumulations decayed when the anticyclonic blocking weakened and cold front crossed over the Pyrenees and followed its path towards the Mediterranean Sea. During the whole episode synoptic and mesoscale ingredients pointed out by Lin et al. (2001) as conducive to orographic rainfall were present (conditionally unstable environment, a LLJ, steep mountain and a quasi-stationary synoptic system). On the other hand, the episode characterized by long-lived $(>12 \mathrm{~h})$ and spatially distributed $\left(>50 \times 50 \mathrm{~km}^{2}\right)$ precipitation could be classified as a Type I event according to the methodology proposed by Molini et al. (2009). Within the framework of that classification, a good estimate of the convective timescale (Molini et al., 2011) would be shorter than $6 \mathrm{~h}$ corresponding to convective equilibrium regime dominated by large-scale forcing. Future work which would require higher density and temporal resolution of precipitation observations could include a predictability analysis of the different event phases similar to that performed by Rebora et al. (2013), or Keil et al. (2013).

Furthermore, the backward trajectories have underlined the mechanism which contributed during phase 2 and 3 to generate the necessary forcing ascent to trigger and maintain the precipitation more than $30 \mathrm{~h}$ over the Pyrenees. For the second phase, in addition to the orographic forcing which triggered or enhanced warm frontal precipitating structures over the Pyrenees, two areas of low-level wind convergence were also identified: one in the west border of Andorra as a result of the deflection role of Pre-Pyrenees and the second over the Canigo region where southerly flows are channelled. For the third phase, strong updraughts are continuously generated all over the windward slopes of the Eastern Pyrenees. Hence the orographic uplift is the dominant lifting mechanism in this HPE which triggered long-lasting precipitating cells over the Pyrenees and Andorra.

The moisture inflow feeding the heavy precipitating cells was found to be confined within the lowest $2000 \mathrm{~m}$ of the atmosphere and its origin mainly within the warm and moist conveyor belt ahead of the cold front. The evolution of the water vapour content during its pathway showed the limited role of the Mediterranean Sea due to the high initial water vapour content of the parcels before entering this area and the rapid crossing of the basin (less than $12 \mathrm{~h}$ ). Particularly, parcels between $1000 \mathrm{~m}$ and $2000 \mathrm{~m}$ had their origin mainly within the warm and moist conveyor ahead of the cold front and almost did not modify its initial moisture content $\left(7 \mathrm{~g} \mathrm{~kg}^{-1}\right)$ before reaching saturation. Furthermore, parcels below $1000 \mathrm{~m}$, which were in contact with the Mediterranean air mass, had elevated initial water content (8-9 $\mathrm{g} \mathrm{kg}^{-1}$ ) and only $2-3 \mathrm{~g} \mathrm{~kg}^{-1}$ could be gained from the Mediterranean. Therefore, for this HPE the moisture coming from remote source regions (Atlantic and African air masses) is larger than the local moisture source. These results are in good agreement with Duffourg and Ducrocq (2011), who concluded that when cyclonic conditions prevail before the HPE the amounts of moisture gained from the Mediterranean is remarkably lower $\left(3-4 \mathrm{~g} \mathrm{~kg}^{-1}\right)$, and also with Pinto et al. (2013) who studied a large data set of HPEs affecting north-west Italy and concluded that the most intense events were characterized by a significant moisture advection from the Atlantic Ocean.

This present study strengthens the importance of the slow-evolving synoptic conditions and the strong cyclonic flow induced by the deep Atlantic low. Moreover it contributes to quantify the mesoscale ingredients as the substantial moisture advection from the Atlantic Ocean and details the crucial role of the Pyrenees in the major flash-flood event recorded in Andorra.

\section{Appendix A}

\section{A fuzzy verification of the high resolution QPF}

To objectively complement the previous qualitative evaluation presented in Sect. 3.2, two fuzzy verification techniques have been applied to $48 \mathrm{~h}$ accumulation forecasts at $2.5 \mathrm{~km}$ spatial resolution. The validation is focused on the sub-domain of $105 \times 100$ grid boxes shown in Fig. 7. As described in Ebert (2008), opposite to traditional verifications, neighbourhood (fuzzy) verification assumes that it is acceptable for the forecast to be slightly displaced and still be useful. As we are interested in verifying the forecast in particular locations of interest (raingauge observations) two methods that follow a single observation-neighbourhood forecast strategy were chosen (Ebert, 2008): the multi-event contingency table (ME) and the conditional square root of RPS (CS).

The ME method (Atger, 2001) considers a forecast useful if it predicts at least one event close to an observed event. An event is the occurrence of a value exceeding a certain threshold of rainfall intensity (i.e. $\mathrm{mm} / 48 \mathrm{~h}$ ). The standard score used for that method is the Hansen and Kuipers (HK) score:

$$
H K=H-F,
$$

where

$$
\begin{aligned}
H & =\frac{\text { hits }}{\text { hits+misses }} \\
F & =\frac{\text { false.alarms }}{\text { false.alarms+correct.rejections }} .
\end{aligned}
$$

The HK measures the ability of the forecast system to separate the observed "yes" cases from the "no" cases.

The CS method (German and Zawadzki, 2004) represents the following decision model: "A useful forecast is one that has a high probability of matching the observed value". Unlike ME method, the CS includes the intensity directly 

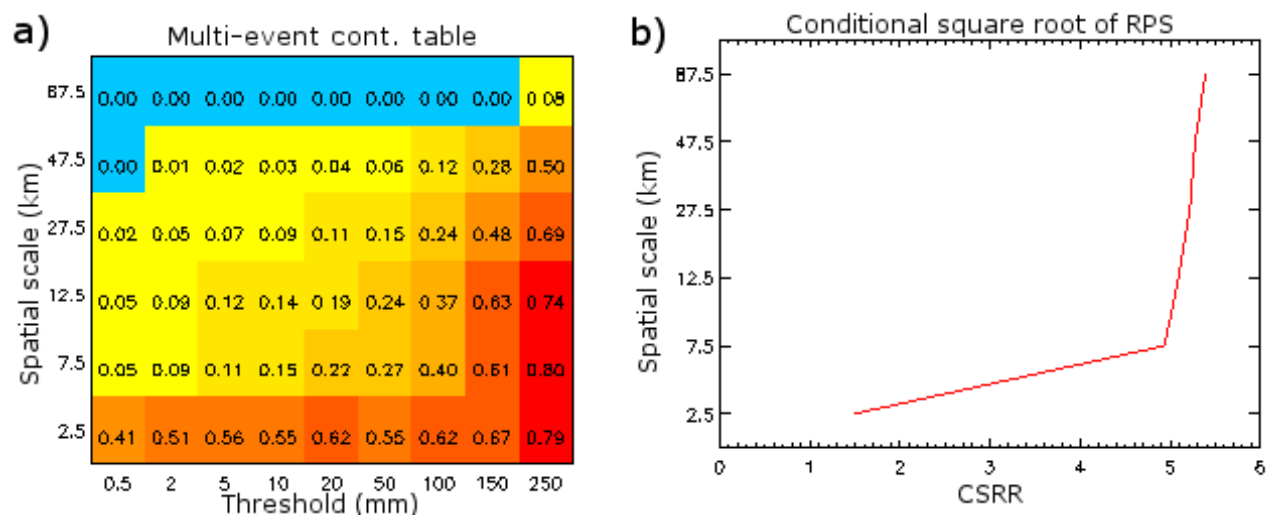

Fig. A1. Fuzzy verification of the precipitation forecast shown in Fig. 7: multi-event contingency table showing the HK score (left panel) and conditional square root of RPS (right panel). The red colours on the left panel indicate good performance according to the decision model used by the ME method, while blue colours indicate poor skill.

into the calculation of scores instead of verifying the occurrence or probability of events. The score used is

$\mathrm{CSRR}=\frac{\sqrt{\mathrm{RPS}}}{\overline{P_{x>0}}}$

with

$\left.\operatorname{RPS}=\frac{1}{M-1} \sum_{m=1}^{M}\left(\mathrm{CDF}_{y, m}-o_{m}\right)^{2}\right)$,

where $M$ is the number of forecast categories and $\mathrm{CDF}_{y, m}$ is the cumulative probability of the forecast exceeding the threshold for category $m$, and $o_{m}$ is an indicator $(0=$ no, $1=$ yes) for the observation in category $m$.

A perfect forecast would have a score of 1 for $\mathrm{HK}$ and 0 for CSRR. Figure A1 shows the fuzzy verification results from both techniques. For ME method results vary in both intensity and spatial scale ( $x$ and $y$ axes, respectively). This approach allows us to identify the scale-intensity combination at which the highest resolution forecast performs better. CSRR results are only a function of neighbourhood window size (spatial scale).

The HK score presents the highest values for extreme intensities $(>250 \mathrm{~mm})$ and low to moderate scales $(2.5$ to $27.5 \mathrm{~km}$ ), showing the skill of the model in predicting the heaviest precipitation close (few $\mathrm{km}$ ) to the observations. For spatial scales it is the finest grid $(2.5 \mathrm{~km})$ the one that achieves highest values for light and moderate intensities. It can be interpreted that at high spatial resolution the forecast predicted rain rates of similar magnitude as that of the observations. The large number of hits and correct rejections highlight the model performance in detecting the strong spatial gradient of precipitation over the complex topography of the study area. Finally, the CSRR confirms that it is at finest scales $(2.5 \mathrm{~km})$ where the best match between forecast and the observed intensity distribution is detected - see the decreasing values of CSRR with decreasing spatial scales, with a minimum at $2.5 \mathrm{~km}$.
Acknowledgements. The authors appreciate the collaboration of SMC (Meteorological Service of Catalonia), especially Marc Prohom regarding the computation and quality control of the 24-hour rainfall data from AEMET (Spanish Meteorological Agency). We would like also to thank AEMET, Météo-France (French Meteorological Office) and Eumetsat for surface observations and satellite data, respectively. We also thank Beth Ebert (BMRC) for providing the "fuzzy verification toolbox" (available online at http: //www.cawcr.gov.au/projects/verification/fuzzy_verification.zip).

The comments of the reviewers are also gratefully acknowledged. This study has been done in the framework of the HYMEX project. This research was partly funded by the project CGL2012-38945 granted to the University of Barcelona by the Spanish Ministry of Economic Affairs and Competitiveness. Finally, the IEA (Andorran Research Institut) acknowledges the help of the Govern d'Andorra in the framework of the research grants of the Comunitat de Treball dels Pirineus (CTP013-AND/2012).

Edited by: A. Mugnai

Reviewed by: two anonymous referees

\section{References}

Albentosa, L. M.: Precipitaciones excepcionales e inundaciones durante los días 6 al 8 de noviembre de 1982 en Cataluña, Estudios Geográficos, 170-171, Madrid, 1983 (in Spanish).

Atger, F.: Verification of intense precipitation forecasts from single models and ensemble prediction systems, Nonlin. Processes Geophys., 8, 401-417, doi:10.5194/npg-8-401-2001, 2001.

Barthélemy, L.: Aiguat des 7-8 Novembre 1982, intensité et quantités de précipitations estimées. Centre d'Études Andorranes-Perpignan, Centre de Géographie Physique H. Elhaï - Univ. Paris, 1982 (in French).

Barredo, J. I.: Major Flood Disasters in Europe: 1950-2005, Nat. Hazards, 42, 125-148, 2007.

Batalla, M., Ninyerola, M., and Esteban, P.: Atles Climàtic Digital d'Andorra, Servidor de mapes, Institut d'Estudis Andorrans (IEA) i Universitat Autònoma de Barcelona (UAB), available at: 
http://opengis.uab.es/wms/ACDA/index.htm (last access: April 2013), 2011 (in Catalan).

Bechtold, P., Bazile, E., Guichard, F., Mascart, P., and Richard, E.: A mass flux convection scheme for regional and global models, Q. J. Roy. Meteor. Soc., 127, 869-886, 2001.

Bresson, E., Ducrocq, V., Nuissier, O., Ricard, D., and de SaintAubin, C.: Idealized numerical simulations of quasi-stationary convective systems over the Northwestern Mediterranean complex terrain, Q. J. Roy. Meteor. Soc., 138, 1751-1763, doi:10.1002/qj.1911, 2012.

Cailleau, C. and Santurette, P.: Têmpete des 6, 7 et 8 novembre 1982, Note de Travail du Service Météorologique Métropolitain, 10, Ministère des Transports, Direction de la Météorologie, France, 1983 (in French).

Caniaux, G., Redelsperger, J.-L., and Lafore, J.-P.: A numerical study of the stratiform region of a fast-moving squall line, J. Atmos. Sci., 51, 2046-2074, 1994.

Commission Météorologique Départementale: Annales climatologiques 1982, Pyrénnées-Orientales, Conseil Général, 1982 (in French).

Corominas, J. and Alonso, E. E.: Geomorphological effects of extreme floods (November 1982) in the southern Pyrenees. Hydrology in Mountainous Regions, Proceedings of two Lausanne Symposia, August 1990, IAHS Publ. no. 194, available at: http://iahs.info/redbooks/a194/iahs_194_0295.pdf (last access: February 2013), 1990.

Cuxart, J., Bougeault, P., and Redelsperger, J.-L.: A turbulence scheme allowing for mesoscale and large-eddy simulations, Q. J. Roy. Meteor. Soc., 126, 1-30, doi:10.1002/qj.49712656202, 2000.

Dee, D. P., Uppala, S. M., Simmons, A. J., Berrisford, P., Poli, P., Kobayashi, S., Andrae, U., Balmaseda, M. A., Balsamo, G., Bauer, P., Bechtold, P., Beljaars, A. C. M., van de Berg, L., Bidlot, J., Bormann, N., Delsol, C., Dragani, R., Fuentes, M., Geer, A. J., Haimberger, L., Healy, S. B., Hersbach, H., Hólm, E. V., Isaksen, L., Kållberg, P., Köhler, M., Matricardi, M., McNally, A. P., Monge-Sanz, B. M., Morcrette, J.-J., Park, B.-K., Peubey, C., de Rosnay, P., Tavolato, C., Thépaut, J.-N., and Vitart, F.: The ERA-Interim reanalysis: configuration and performance of the data assimilation system, Q. J. Roy. Meteor. Soc., 137, 553-597, doi:10.1002/qj.828, 2011.

Duffourg, F. and Ducrocq, V.: Origin of the moisture feeding the Heavy Precipitating Systems over Southeastern France, Nat. Hazards Earth Syst. Sci., 11, 1163-1178, doi:10.5194/nhess-111163-2011, 2011.

Ebert, E. E.: Fuzzy verification of high-resolution gridded forecasts: A review and proposed framework, Meteor. Appl., 15, 51-64, 2008.

Esteban, P., Ninyerola, M., and Prohom, M.: Spatial modelling of air temperature and precipitation for Andorra (Pyrenees) from daily circulation patterns. Theor. Appl Climatol., 96.1, 43-56, 2009.

Fresnay, S., Hally, A., Garnaud, C., Richard, E., and Lambert, D.: Heavy precipitation events in the Mediterranean: sensitivity to cloud physics parameterisation uncertainties, Nat. Hazards Earth Syst. Sci., 12, 2671-2688, doi:10.5194/nhess-12-2671-2012, 2012.

Gallego, N.: Cadastre de riscos naturals a Andorra, Horitzó 5, 1627, 2003 (in Catalan).
Gaume, E, Bain, V., Bernardara, P., Newinger, O ., Barbuc, M., Bateman, A., Blaškovičová, L., Blöschl, G., Borga, M., Dumitrescu, A., Daliakopoulos, I., Garcia, J ., Irimescu, A., Kohnova, S., Koutroulis, A., Marchi, L., Matreata, S., Medina, V., Preciso, E., Sempere-Torres, D., Stancalie, G., Szolgay, J., Tsanis, I., Velasco, D., and Viglione, A.: A compilation of data on European flash floods. J. Hydrol., 367, 70-78, doi:10.1016/j.jhydrol.2008.12.028, 2009.

Germann, U. and Zawadzki, I.: Scale dependence of the predictability of precipitation from continental radar images, Part II: probability forecasts, J. Appl. Meteorol., 43, 74-89, 2004.

Gheusi, F. and Stein, J.: Lagrangian description of airflows using Eulerian passive tracers, Q. J. Roy. Meteor. Soc., 128, 337-360, doi:10.1256/00359000260498914, 2002.

Gutiérrez, F., Gutiérrez, M., and Sancho, C.: Geomorphological and sedimentological analysis of a catastrophic flash flood in the Arás drainage basin (Central Pyrenees, Spain), Geomorphology, 22, 265-283, 1998.

Harrold, T. W.: Mechanisms influencing the distribution of precipitation within baroclinic disturbances, Q. J. Roy. Meteor. Soc., 99, 232-251, 1973.

Hoskins, B. J., McIntyre, M. E., and Robertson, A. W.: On the use and significance of isentropic potential vorticity maps, Q. J. Roy. Meteor. Soc., 111, 877-946, 1995.

Houze Jr., R. A.: Orographic effects on precipitating clouds, Rev. Geophys., 50, RG1001, doi:10.1029/2011RG000365, 2012.

Jansà, J. M.: La masa de aire Mediterránea, Rev. de Geofísica, 69, 35-50, 1959 (in Spanish).

Keil, C., Heinlein, F., and Craig, G. C.: The convective adjustment time-scale as indicator of predictability of convective precipitation, Q. J. Roy. Meteor. Soc., doi:10.1002/qj.2143, online first, 2013.

Lafore, J. P., Stein, J., Asencio, N., Bougeault, P., Ducrocq, V., Duron, J., Fischer, C., Héreil, P., Mascart, P., Masson, V., Pinty, J. P., Redelsperger, J. L., Richard, E., and Vilà-Guerau de Arellano, J.: The Meso-NH Atmospheric Simulation System. Part I: adiabatic formulation and control simulations, Ann. Geophys., 16, 90-109, doi:10.1007/s00585-997-0090-6, 1998.

Lin, Y. L., Chiao, S., Wang, T., Kaplan, M. L., and Weglarz., R. P.: Some Common Ingredients for Heavy Orographic Rainfall, Weather Forecast., 16, 633-660, 2001.

Llasat, M. C.: Gota Fría, Editorial Boixareu Universitaria, 139-150 pp., ISBN: 84-267-0829-3, 1991 (in Spanish).

Marti-Bono, C. and Puigdefabregas, J.: Consecuencias geomorfologicas de las lluvias de noviembre de 1982 en las cabeceras de algunos valles pirenaicos, Estud. Geogr., 170-171, 275-290, 1983 (in Spanish).

Météo-France: 6 au 8 novembre 1982 Tempête et inondations majeures sur le grand Sud. Pluies extremes, Météo-France, available at: http://pluiesextremes.meteo.fr/1982-11-06/ tempete-sur-1-ouest-de-1-europe-et-ravages-sur-le-sud.html (last access: January 2013), 2012 (in French).

Migletta, M. M. and Rotunno, R.: Numerical simulations of conditionally unstable flows over a mountain ridge, J. Atmos. Sci., 66, 1865-1885, doi:10.1175/2009JAS2902.1, 2009.

Molini, L., Parodi, A., and Siccardi, F.: Dealing with uncertainty: an analysis of the severe weather events over Italy in 2006, Nat. Hazards Earth Syst. Sci., 9, 1775-1786, doi:10.5194/nhess-91775-2009, 2009. 
Molini, L., Parodi, A., Rebora, N., and Craig, G. C.: Classifying severe rainfall events over Italy by hydrometeorological and dynamical criteria. Q. J. Roy. Meteor. Soc., 137, 148-154, 2011.

Nuissier, O., Ducrocq, V., and Ricard, D.: A numerical study of three catastrophic precipitating events over southern France. Part I: Numerical framework and synoptic ingredients, Q. J. Roy. Meteor. Soc., 134, 111-130, doi:10.1002/qj.200, 2008.

Nuissier, O., Joly, B., Joly, A., Ducrocq, V., and Arbogast, P.: A statistical downscaling to identify the large-scale circulation patterns associated with heavy precipitation events over southern France, Q. J. Roy. Meteor. Soc., 137, 1812-1827, doi:10.1002/qj.866, 2011.

Pergaud, J., Masson, V., Malardel, S., and Couvreux, F.: A parameterization of dry thermals and shallow cumuli for mesoscale numerical weather prediction, Bound.-Lay. Meteorol., 132, 83-106, doi:10.1007/s10546-009-9388-0, 2009.

Pinto, J. G., Ulbrich, S., Parodi, A., Rudari, R., Boni, G., and Ulbrich, U.: Identification and ranking of extraordinary rainfall events over Northwest Italy: The role of Atlantic moisture, J. Geophys. Res.-Atmos., 118, 2085-2097, doi:10.1002/jgrd.50179, 2013.

Pinty, J.-P. and Jabouille, P.: A mixed-phased cloud parametrization for use in a mesoscale non-hydrostatic model: Simulations of a squall line and of orographic precipitation. Proceedings of the Conference on Cloud Physics, Amer. Meteorol. Soc: Boston, Everett, WA, USA, August 1999, 217-220, 1998.

Ramis, C.: Las observaciones de la atmósfera libre en Mallorca: una breve historia y algunos resultados, Rev. de Ciéncia, 17, 41-58, 1995 (in Spanish).

Rebora, N., Molini, L., Casella, E., Comellas, A., Fiori, E., Pignone, F., Siccardi, F., Silvestro, F., Tanelli, S., and Parodi A.: Extreme rainfall in the Mediterranean: what can we learn from observations?, J. Hydrometeorol., 14, 906-922, doi:10.1175/JHM-D-12-083.1, 2013.
Ricard, D., Ducrocq, V., and Auger, L.: A climatology of mesoscale environment associated with Mediterranean Heavy Precipitating Events over a Northwestern Mediterranean area, J. Appl. Meteorol. Clim., 51, 468-488, 2012.

Riosalido, R., Ferraz, J., Alvarez, E., Cansado, A., Martín, F., Elízaga, F., Camacho, J. L., and Martín, A.: A flash flood event in the Spanish Pyrenees: the Biescas case, INM, in: WMO International Symposium on cyclones and hazardous weather in the Mediterranean, Palma de Mallorca, 151-158, 1998.

Seity, Y., Brousseau, P., Malardel, S., Hello, G., Benard, P., Bouttier, F., Lac, C., and Masson, V.: The AROME-France ConvectiveScale Operational Model., Mon. Weather Rev., 139, 976-991, 2011.

Semple, A. T.: A review and unification of conceptual models of cyclogenesis, Meteorol. Appl., 10, 39-59, 2003.

Sotillo, M. G., Ramis, C., Romero, R., Alonso, S., and Homar, V.: Role of orography in the spatial distribution of precipitation over the Spanish Mediterranean zone, Clim. Res., 23, 247-261, 2003.

Trapero, L., Gallego N., Margalef A., and Esteban P.: Analysis of a flood event that affected the Hispano-Andorran border the 1st August 2008, Poster in the IMPRINTS Workshop, February 2011, Toulouse, France, 2011.

Trapero, L., Bech, J., and Lorente, J.: Numerical modelling of heavy precipitation events over Eastern Pyrenees: Analysis of orographic effects, Atmos. Res., 123, 368-383, doi:10.1016/j.atmosres.2012.09.014, 2013.

Vié, B., Molinié, G., Nuissier, O., Vincendon, B., Ducrocq, V., Bouttier, F., and Richard, E.: Hydro-meteorological evaluation of a convection-permitting ensemble prediction system for Mediterranean heavy precipitating events, Nat. Hazards Earth Syst. Sci., 12, 2631-2645, doi:10.5194/nhess-12-2631-2012, 2012. 